\title{
Pain, Depression, and Quality of Life in Neuromyelitis Optica Spectrum Disorder
}

\section{A Cross-Sectional Study of 166 AQP4 Antibody-Seropositive Patients}

Ilya Ayzenberg, MD, Daniel Richter, MD, Eugenia Henke, MD, Susanna Asseyer, MD, Friedemann Paul, MD, Corinna Trebst, MD, Martin W. Hümmert, MD, Joachim Havla, MD, Tania Kümpfel, MD, Marius Ringelstein, MD, Orhan Aktas, MD, Brigitte Wildemann, MD, Sven Jarius, MD, Vivien Häußler, MD, Jan-Patrick Stellmann, MD, Makbule Senel, MD, Luisa Klotz, MD, Hannah L. Pellkofer, MD, Martin S. Weber, MD, Marc Pawlitzki, MD, Paulus S. Rommer, MD, Achim Berthele, MD, Klaus-Dieter Wernecke, MD, PhD, Kerstin Hellwig, MD, Ralf Gold, MD, and Ingo Kleiter, MD, on behalf of the NEMOS (Neuromyelitis Optica Study Group)

Neurol Neuroimmunol Neuroinflamm 2021;8:e985. doi:10.1212/NXI.0000000000000985

\section{Abstract}

\section{Objectives}

To evaluate prevalence, clinical characteristics, and predictors of pain, depression, and their impact on the quality of life (QoL) in a large neuromyelitis optica spectrum disorder (NMOSD) cohort.

\section{Methods}

We included 166 patients with aquaporin-4-seropositive NMOSD from 13 tertiary referral centers. Patients received questionnaires on demographic and clinical characteristics, PainDetect, short form of Brief Pain Inventory, Beck Depression Inventory-II, and Short Form 36 Health Survey.

\section{Results}

One hundred twenty-five (75.3\%) patients suffered from chronic NMOSD-associated pain. Of these, $65.9 \%$ had neuropathic pain, $68.8 \%$ reported spasticity-associated pain and $26.4 \%$ painful tonic spasms. Number of previous myelitis attacks $(\mathrm{OR}=1.27, p=0.018)$ and involved upper thoracic segments $(\mathrm{OR}=1.31, p=0.018)$ were the only predictive factors for chronic pain. The latter was specifically associated with spasticity-associated pain $(\mathrm{OR}=1.36, p=0.002)$. More than a third (39.8\%) suffered from depression, which was moderate to severe in $51.5 \%$. Pain severity $(\mathrm{OR}=1.81, p<0.001)$ and especially neuropathic character $(\mathrm{OR}=3.44, p<0.001)$ were associated with depression. Pain severity and walking impairment explained $53.9 \%$ of the physical QoL variability, while depression and walking impairment 39.7\% of the mental QoL variability. No specific medication was given to $70.6 \%$ of patients with moderate or severe depression and $42.5 \%$ of those with neuropathic pain. Two-thirds (64.2\%) of patients with symptomatic treatment still reported moderate to severe pain.

\author{
Correspondence \\ Dr. Kleiter \\ ingo.kleiter@rub.de
} From the Department of Neurology (I.A., D.R., E.H., K.H., R.G., I.K.), St. Josef-Hospital, Ruhr-University Bochum, Germany; Department of Neurology (I.A.), Sechenov First Moscow
State Medical University, Russia; NeuroCure Clinical Research Center (S.A., F.P.), Charité Universitätsmedizin Berlin, Berlin Institute of Health, Corporate Member of Freie Universität
Berlin, Humboldt-Universität zu Berlin, Germany; Department of Neurology (C.T., M.W.H.), Hannover Medical School, Germany; Institute of Clinical Neuroimmunology (.H., T.K.,
H.L.P.), University Hospital and Biomedical Center, Ludwig-Maximilians University Munich, Germany; Department of Neurology (M.R., O.A.), Medical Faculty, Heinrich Heine University
Düsseldorf, Germany; Department of Neurology (M.R.), Center for Neurology and Neuropsychiatry, LVR-Klinikum Düsseldorf, Germany; Molecular Neuroimmunology Group (B.W.,,
S.J.), Department of Neurology, University of Heidelberg, Germany; Institut für Neuroimmunologie und Multiple Sklerose (INIMS) (V.H., J.-P.S.), Zentrum für Molekulare Neurobiologie,
Hamburg, Germany; Klinik und Poliklinik für Neurologie (V.H.,J.-P.S.), Universitätsklinikum Hamburg-Eppendorf, Germany; APHM (J.-P.S.), Hopital de la Timone, CEMEREM, Marseille,
France; Aix Marseille Université (J.-P.S.), CRMBM, CNRS UMR 7339, Marseille, France; Department of Neurology (M.S.), University of Ulm, Germany; Münster Department of Neurology
with Institute of Translational Neurology (L.K., M.P.), University Hospital Münster, Germany; Department of Neurology (H.L.P., M.S.W.), University Medical Center, Göttingen, Germany;
Department of Neurology (M.P.), Otto-von-Guericke University, Magdeburg, Germany; Department of Neurology (P.S.R.), Medical University of Vienna, Austria; Neuroimmunology
Section (P.S.R.), Department of Neurology, University of Rostock, Germany; Department of Neurology (A.B.), School of Medicine, Technical University of Munich, Germany; Charité-
Universitätsmedizin Berlin, CRO SOSTANA GmbH Berlin (K.-D.W.), Germany; and Marianne-Strauß-Klinik (I.K.), Behandlungszentrum Kempfenhausen für Multiple Sklerose Kranke
gGmbH, Berg, Germany.

Go to Neurology.org/NN for full disclosures. Funding information is provided the end of the article.

The Article Processing Charge was funded by the authors.

Coinvestigators are listed in Appendix 2.

This is an open access article distributed under the terms of the Creative Commons Attribution-NonCommercial-NoDerivatives License 4.0 (CC BY-NC-ND), which permits downloading and sharing the work provided it is properly cited. The work cannot be changed in any way or used commercially without permission from the journal. 


\section{Glossary}

ADL $=$ activity of daily living; BDI $=$ Beck Depression Inventory; EDSS $=$ Expanded Disability Status Scale; MCS = mental component summary; MPQ-SF = McGill Pain Questionnaire Short Form; NMOSD = neuromyelitis optica spectrum disorder; PDQ = PainDetect questionnaire; PTS = painful tonic spasm.

\section{Conclusions}

Myelitis episodes involving upper thoracic segments are main drivers of pain in NMOSD. Although pain intensity was lower than in previous studies, pain and depression remain undertreated and strongly affect QoL. Interventional studies on targeted treatment strategies for pain are urgently needed in NMOSD.

Neuromyelitis optica spectrum disorder (NMOSD) is an autoimmune inflammatory disorder that primarily affects the visual pathway, brain, and spinal cord. ${ }^{1,2}$ Autoantibodies targeting aquaporin-4 (AQP4) are present in the majority of patients and proved to be pathogenic in animal models. ${ }^{3,4}$ NMOSD attacks often do not fully recover and residual clinical deficits remain in $>75 \%$ of attacks. ${ }^{5,6}$ Beside severe physical impairments, NMOSD can go along with symptoms like chronic pain, cognitive deficits, and depression. ${ }^{7,8}$

Spinal pain, girdle-like dysesthesia, and painful spasms were noted already in earliest disease descriptions in the 18 th century. ${ }^{9}$ Nowadays, it has become clear that pain is a frequent and one of the most disabling symptoms of NMOSD., ${ }^{80-15}$ Chronic NMOSD-associated pain affects quality of life (QoL), with pain severity being the most important predictive factor. ${ }^{10,12,13,15}$ Possible underlying mechanisms include damage of the central nociceptive and antinociceptive pathways, particularly the dorsal horn of the spinal cord and the dorsal root entry zone, autonomic thoracolumbar nuclei, the periaqueductal gray, and hypothalamus. Excessive levels of extracellular glutamate and increase of proinflammatory factors, such as interleukin (IL)-6, $\mathrm{IL}-17$, and $\mathrm{C} 5 \mathrm{a}$, can additionally facilitate nociceptive processing. ${ }^{16}$ Glutamate excitotoxicity can cause an imbalance between excitation and inhibition in nociceptive system, resulting in spontaneous neuropathic pain.

Because of the rarity of NMOSD, most previous studies of pain were relatively small. ${ }^{10,11,17}$ Moreover, several studies included a mixed population of AQP4-IgG-seropositive and -seronegative patients, ${ }^{10-13,15}$ whereas recent clinical trials clearly indicate that pathogenetic mechanisms are different in these forms. ${ }^{18}$ Accordingly, data on clinical and paraclinical predictors of pain as well as its association with depression and effects on QoL remain limited.

We sought to investigate clinical characteristics, risk factors, and impact of pain syndromes and depression in a Central European cohort of patients with AQP4-IgG-seropositive NMOSD. Furthermore, we wanted to evaluate the efficacy of immunotherapies and symptomatic treatment for both conditions and search for a short screening question to detect patients with disabling pain.

\section{Methods}

\section{Patients}

We performed an exploratory, questionnaire-based, crosssectional study in the years 2017-2019. Patients with AQP4IgG-seropositive NMOSD according to IPND criteria ${ }^{19}$ were identified through the registry of the German Neuromyelitis Optica Study Group (NEMOS, nemos-net.de). Details on the registry, participating centers, and data collection, quality and processing can be found in previous publications. ${ }^{5,6}$ Inclusion criteria were (1) age over 18 years and (2) positive AQP4IgG, confirmed in a cell-based assay. Patients with known relevant cognitive deficits were excluded. All patients were in remission during the study. Clinical data, including Expanded Disability Status Scale (EDSS), therapies, and localization of spinal lesions in cervical and thoracic segments on MRI, were retrieved from the NEMOS database or local patient records. Data on current pain, depression, walking, and visual impairment and QoL were captured by self-reporting questionnaires. Patients were instructed to report on NMOSDassociated pain syndromes only.

\section{Questionnaires}

Current pain was assessed using the PainDetect questionnaire (PDQ), ${ }^{20}$ the short form of the Brief Pain Inventory (SF$\mathrm{BPI}$ ), and the McGill Pain Questionnaire Short Form (MPQSF). ${ }^{21}$ The questions of the SF-BPI consist of 2 categories: (1) pain severity (present, highest, least, and average pain) based on a Numeric Rating Scale (NRS) from 0 (no pain) to 10 (worst pain imaginable) within the last week. The pain severity index score represents the average score of these 4 pain intensity scores. (2) Seven domains of pain-related interference in activity of daily living $(\mathrm{ADL})$, rated from of 0 (no interference) to 10 (complete interference): general activity, mood, walking ability, working ability, relations with other people, sleep, and enjoyment of life. The PDQ was administered to evaluate pain localization and discriminate between definite neuropathic (PDQ score $>18$ ), probable neuropathic (PDQ score 13-18), and nociceptive pain (PDQ score $<13$ ). The MPQ-SF consists of 15 words, describing sensory (11 words) and affective (4 words) components of pain. Patients rate their intensity as $0=$ none, $1=$ mild, $2=$ moderate, or $3=$ 
severe. Three pain scores are derived from the sum of the rank values: (1) sensory, (2) affective, and (3) total descriptors. Painful tonic spasms (PTSs) were assessed asking the patient whether they experienced recurrent attacks or short episodes (duration < 1 minute) of localized muscle spasms, accompanied by severe pain.

Depression was evaluated using Beck Depression Inventory II (BDI-II), scored from 0 (best) to 63 (worst) (<9: no depressive affect; 9-13: minimal mood disturbance; 14-20: mild depression, 21-28: moderate depression; and $\geq 29$ : severe depression). Clinically relevant depression was defined by a score of $\geq 14$. Health-related QoL was measured with the SF-36 questionnaire, consisting of 36 items in 8 subscales. A Physical

Table 1 Demographic Characteristics and Immunotherapy

\begin{tabular}{|c|c|c|}
\hline & \multicolumn{2}{|c|}{$\begin{array}{l}\text { Mean (SD)/Median } \\
\text { (min-max.) }\end{array}$} \\
\hline $\begin{array}{l}\text { Total number of patients } \\
\text { (all AQP4-IgG seropositive) }\end{array}$ & \multicolumn{2}{|l|}{166} \\
\hline F:M ratio & \multicolumn{2}{|l|}{$8.2: 1$} \\
\hline EDSS & \multicolumn{2}{|l|}{$3.5(0.0-9.0)$} \\
\hline Age, y & \multicolumn{2}{|l|}{$51.7(13.4)$} \\
\hline Disease duration, $y$ & \multicolumn{2}{|l|}{$9.1(8.1)$} \\
\hline ARR & \multicolumn{2}{|l|}{$1.1(1.6)$} \\
\hline $\begin{array}{l}\text { Total number of ON episodes since } \\
\text { onset }\end{array}$ & \multicolumn{2}{|l|}{$2.2(4.1)$} \\
\hline $\begin{array}{l}\text { Total number of myelitis episodes since } \\
\text { onset }\end{array}$ & \multicolumn{2}{|l|}{$4.6(7.4)$} \\
\hline $\begin{array}{l}\text { Total number of involved spinal } \\
\text { segments }\end{array}$ & \multicolumn{2}{|l|}{$5.3(4.1)$} \\
\hline No. of involved cervical segments & \multicolumn{2}{|l|}{$2.2(2.1)$} \\
\hline No. of involved thoracic segments & \multicolumn{2}{|l|}{$3.2(3.3)$} \\
\hline AQP4-IgG titer (CBA) & \multicolumn{2}{|c|}{$1: 100(1: 10-1: 25.600)$} \\
\hline Current immunotherapy & & $\%, \mathbf{N}$ \\
\hline Rituximab & & $\begin{array}{l}62.7 \% \\
104^{\mathrm{a}}\end{array}$ \\
\hline Azathioprine & & $12.0 \%, 20$ \\
\hline Anti-IL6 therapy (tocilizumab $\mathrm{N}=11, \mathrm{SA} 23$ & $N=1)$ & $7.2 \%, 12$ \\
\hline Mycophenolate mofetil & & $4.8 \%, 8$ \\
\hline $\begin{array}{l}\text { Other therapies (methotrexate } N=2 \text {, pre } \\
\text { mitoxantrone } N=2 \text {, IVIg } N=1 \text {, glatiramer } \\
\text { cyclosporin } N=1 \text { ) }\end{array}$ & $\begin{array}{l}\text { nisone } \mathbf{N}=2, \\
\text { acetate } \mathrm{N}=1\end{array}$ & $5.4 \%, 9$ \\
\hline Prednisone as add-on therapy & & $10.2 \%, 17$ \\
\hline No immunotherapy & & $7.8 \%, 13$ \\
\hline
\end{tabular}

Abbreviations: $\mathrm{ARR}=$ annualized relapse rate; $\mathrm{AQP} 4=$ aquaporin-4; $\mathrm{CBA}=$ cell-based assay; EDSS = Expanded Disability Status Scale; F:M = female: male; $\mathrm{ON}=$ optic neuritis.

a Five in combination with oral immunosuppressive agents.
Component Summary (PCS) and a Mental Component Summary (MCS) were calculated using norm-based attaining values from 0 (worst) to 100 (best).

\section{Standard Protocol Approvals, Registrations, and Patient Consents}

Ethics approval was obtained from the Institutional Review Board of the Ruhr-University Bochum (\#15-5534). Ethics approval of the NEMOS registry was obtained in participating centers locally. Patients provided written informed consent. The study was performed according to International Conference on Harmonization/Good Clinical Practice and current legal requirements.

\section{Statistical Analysis}

Descriptive statistics were used to describe sample data. Comparisons of interval-scaled variables were performed using the 2-sample $t$ test for normally distributed variables, the MannWhitney-Wilcoxon rank-sum test for nonparametric or ordinalscaled variables, and the $\chi^{2}$ test for categorical variables. We used binary logistic regression to evaluate factors associated with overall pain (yes vs no) as well as neuropathic (neuropathic vs nociceptive pain) and spasticity-related pain (spasticity-associated vs other [non-spasticity-associated] pain) as dependent variables. The following independent variables were included into the logistic model: sex, age, EDSS, disease duration, AQP4-IgG titer, overall number of previous relapses, number of myelitis attacks, and number of involved spinal segments. Concerning depressive state, sex, age, disease duration, walking, and visual impairment were included into analysis. A multiple robust regression model with backward feature selection was used to determine predictors for hrQoL, with PCS and MCS composites as dependent variables and age, sex, disease duration, walking and visual impairment, pain severity, and Beck depression index as independent variables. $^{22}$ To check for correlations between pain intensity and different aspects of ADL, we performed the Spearman correlation test. This study was an exploratory pilot study, with no a priori sample size calculation. For the same reason, statistical significance was set at $p<0.05$ without adjustment for multiple testing. Numerical calculations were performed by SPSS Statistics, Version 25, SPSS Inc., an IBM Company, and The R Project for Statistical Computing, Version 3.4 .0 (2017-04-21), The R Foundation for Statistical Computing.

\section{Data Availability}

Anonymized data not published within this article are available on reasonable request from any qualified investigator within 5 years after publication.

\section{Results}

\section{Demographic and Clinical Characteristics}

Thirteen tertiary referral NEMOS centers participated in the study, and 172 questionnaires were sent back to the reading center in Bochum for analysis. The response rate was $83.1 \%$ (data on response rate available for 7 centers, addressing 


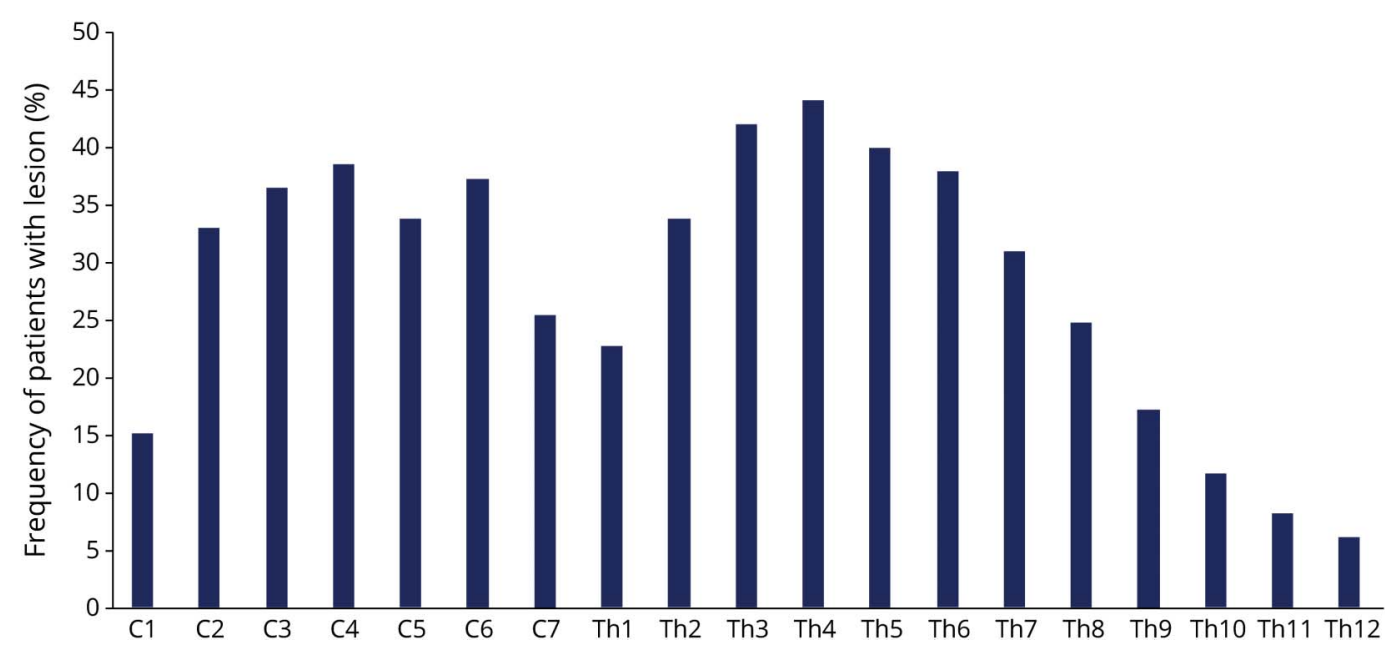

Shown is the frequency (\%) of patients (total $n=143$ ) with a spinal lesion on MRI at the appropriate level.

$71.1 \%$ of respondents). Data of 6 questionnaires were insufficient and had to be excluded. In total, 166 patients with AQP4-IgG-seropositive NMOSD (148 female and 18 male) were included. Main demographic and clinical characteristics are described in table 1 . Most patients in the cohort had a history of myelitis $(152 ; 91.6 \%)$ or optic neuritis (114; $68.7 \%), 95$ (57.2\%) of both myelitis and optic neuritis. Data on the last available spinal MRI were available for 143 of 166 patients (130 of 152 with a history of myelitis) and demonstrated a 2-peak distribution (C2-C6 and Th2-Th7) of lesion location (figure 1). Eleven of 21 patients without visible spinal lesions had a history of myelitis. Six patients only had a relapse in the previous 6 months.

\section{Overall Pain Prevalence and Main Characteristics}

Overall, 125 (75.3\%) patients suffered from chronic NMOSDassociated pain. The intensity of NMOSD-associated chronic pain was moderate to severe in $55.2 \%$ of pain sufferers (figure $2 \mathrm{~A}$ ). Pain was mainly described as aching (90.4\%), tender (76.8\%), stabbing (68.8\%), or burning (66.4\%) on sensory dimensions and tiringexhausting $(68.0 \%)$ on affective dimension. Most prevalent were chronic pain without painless periods $(n=77,61.6 \%)$. Isolated or overlapping pain attacks reported 48 (38.4\%) and $40(32.0 \%)$ patients accordingly (figure $2 \mathrm{~B})$. Every second patient $(\mathrm{n}=88$, $53 \%)$ reported pain as a symptom of the last relapse.

\section{Prevalence of Different Types of Pain}

One-third of pain sufferers had nociceptive ( $n=39,30.7 \%)$, probable neuropathic $(n=43,33.9 \%)$, or definite neuropathic pain $(n=40,31.5 \%)$ each; in 3 patients, the type of pain could not be identified (figure 2C). Pain was most often localized in legs $(72.8 \%$, in two-thirds of cases bilateral), followed by arms (48.8\%, in half of cases bilateral), trunk (34.4\%), and neck/ head region $(27.2 \%)$. Most intense pain were reported by patients with pain localization in the trunk $(4.9 \pm 1.7$ vs $3.3 \pm$ $2.2, p<0.05)$ or legs $(4.1 \pm 2.2$ vs $3.2 \pm 2.0, p<0.05)$. Trunk pains were more often of definite neuropathic than of probable neuropathic or nociceptive character ( $55.8 \%$ vs $27.9 \%$ vs $16.3 \%$; $p<0.05$ ), whereas no changes were found for pains in other regions of the body.

Two-thirds of the pain sufferers reported spasticity-associated pain $(\mathrm{n}=86,68.8 \%)$ (figure $2 \mathrm{D}$ ). It was significantly more prevalent in patients with nociceptive than neuropathic pain ( $87.8 \%$ vs $55.8 \%, p=0.02)$. Thirty-three patients $(26.4 \%)$ had short-lasting PTS, mostly in the legs $(n=28,84.8 \%)$ and rarely in the arms $(n=6,18.2 \%)$. These patients reported approximately 5 PTS episodes a day $(4.9 \pm 6.4)$, with a range of 26 attacks per day to 1 per week.

\section{Episodes of Myelitis Involving Upper Thoracic Segments Are Associated With Chronic Pain}

Chronic pain was not associated with age, sex, AQP4-IgG titer, disease duration, overall disability (EDSS), or depressive state $(\mathrm{BDI}>14)$. However, the number of previous attacks was significantly associated with the occurrence of pain (OR $1.12[1.02-1.21], p=0.020)$. More detailed analysis revealed that the total number of episodes of myelitis (OR 1.27 [1.05-1.57], $p=0.018)$, but not the number of optic neuritis (OR 1.02 [0.92-1.13], $p=0.716$ ), was relevant. There was no association of pain prevalence or severity with the presence or any specific localization of persistent spinal lesions (table 2). However, we found an association of the number of involved spinal segments with pain (OR 1.14 [1.03-1.28], $p=0.024$ ). Moreover, the number of lesions in the upper 6 thoracic segments only (but not in cervical or lower thoracic lesions) was associated with the risk of having pain in general (OR 1.31 [1.01-1.63], $p=0.018$ ) and was the only specific factor increasing the risk of spasticity-associated pain among pain sufferers (OR 1.36 [1.10-1.67], $p=0.002$ ). We could not find any specific factors associated with short-lasting PTS. Depressive state was the only factor strongly associated with neuropathic pain (OR 3.44 [1.35-8.80], $p=0.001$ ). 

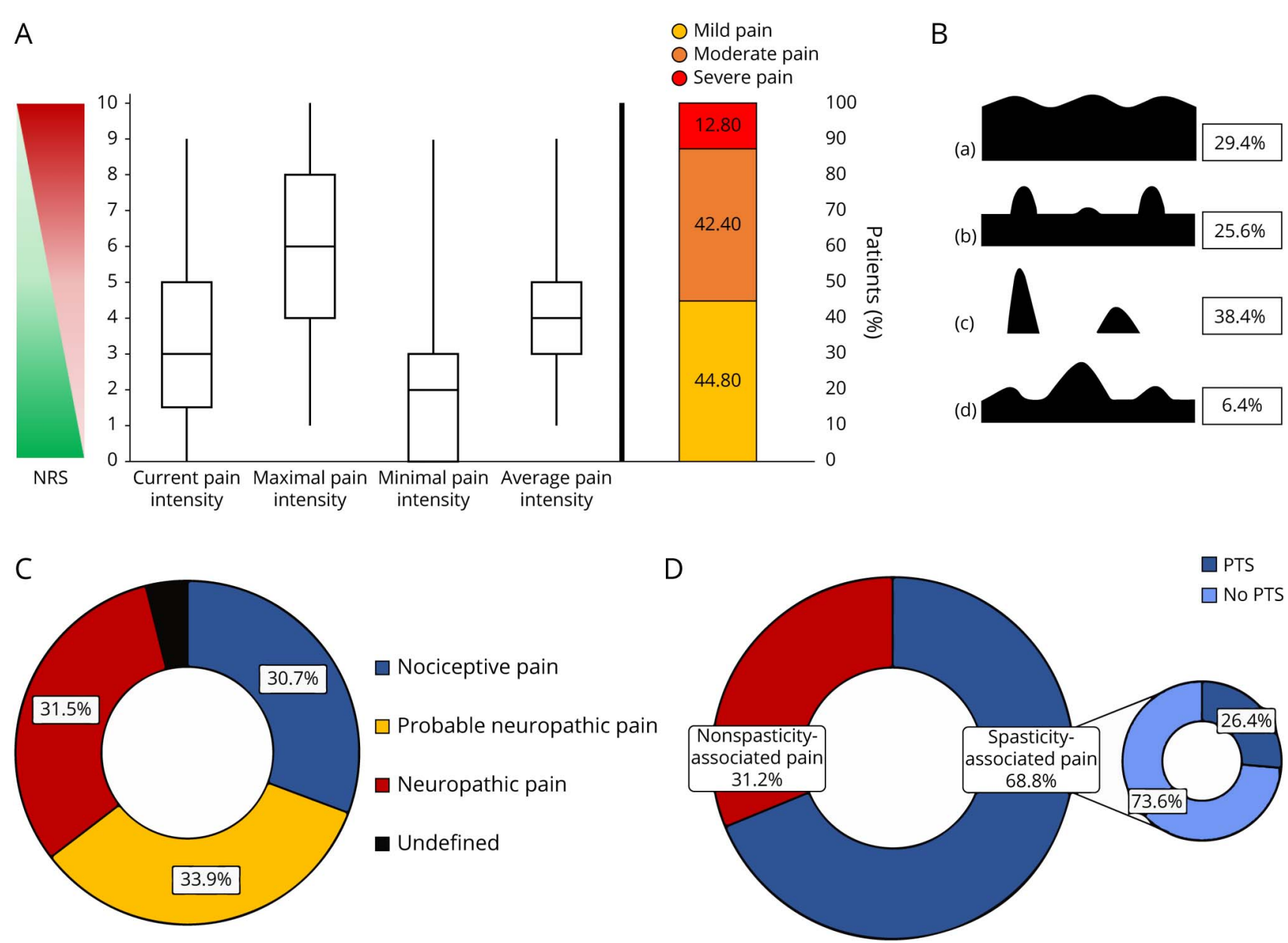

(A) Intensity, (B) temporal patterns (a. continuous pain with slight fluctuations; b. continuous pain with pain attacks; c. pain attacks with painless periods; $d$. pain attacks without painless periods), and (C and D) character of pain. Values of pain intensity are given in median, interquartile range, and minimal and maximal values. Prevalence is given in (\%). NMOSD = neuromyelitis optica spectrum disorder. NRS = Numeric Rating Scale, PTS = painful tonic spasm.

\section{Pain Severity Strongly Correlates With Reduction of Activities of Daily Living}

Effects of pain on ADL are given in table 3. Correlation analysis revealed a strong correlation of pain severity with general activity (rho $=0.69, p<0.001)$ and sleep $(\mathrm{rho}=0.61$, $p<0.001$ ), followed by mood (rho $=0.55, p<0.001$ ), walking ability (rho $=0.54, p<0.001$ ), normal work (rho $=0.52, p<$ $0.001)$, enjoyment of life $(\mathrm{rho}=0.50, p<0.001)$, and relations (rho $=0.46, p<0.001)$. We observed an even stronger negative effect of definite neuropathic pain on all evaluated ADL aspects compared with nociceptive pain.

\section{Chronic Pain But Not Physical Impairment Is Associated With Depression in NMOSD}

Sixty-six (39.8\%) patients suffered from depression: mild in $32(19.3 \%)$, moderate in $21(11.6 \%)$, and severe in $13(7.8 \%)$

Table 2 Prevalence and Severity of Pain in 143 Patients With Spinal Lesions of Different Localizations

\begin{tabular}{|c|c|c|c|}
\hline Localization of spinal lesions & Prevalence of pain & BPI-PSI & PainDetect score \\
\hline No persistent lesions $(\mathrm{N}=\mathbf{2 1}$ ) & $68.2 \%(N=15)^{a}$ & $3.6 \pm 2.4$ & $13.5 \pm 5.1$ \\
\hline Isolated cervical lesions ( $\mathbf{N}=\mathbf{2 7}$ ) & $66.7 \%(\mathrm{~N}=18)$ & $3.4 \pm 1.9$ & $15.0 \pm 7.5$ \\
\hline Isolated thoracic lesions $(\mathrm{N}=33)$ & $81.8 \%(\mathrm{~N}=27)$ & $4.3 \pm 2.2$ & $17.4 \pm 6.7$ \\
\hline Cervicothoracic lesions ( $N=62$ ) & $77.0 \%(\mathrm{~N}=47)$ & $3.7 \pm 2.2$ & $16.2 \pm 6.6$ \\
\hline
\end{tabular}

Abbreviation: BPI-PSI = Pain Severity Index of Brief Pain Inventory.

BPI-PSI and PainDetect Score values are given in mean \pm SD for pain sufferers. No significant differences were found

a Seven of 15 patients had at least 1 myelitis episode in the history. 
Table 3 Effects of Neuropathic and Nociceptive Pain on ADL

\begin{tabular}{llll}
\hline & $\begin{array}{l}\text { All pain } \\
\text { sufferers } \\
\mathbf{( N = 1 2 5 )}\end{array}$ & $\begin{array}{l}\text { Patients with } \\
\text { definite } \\
\text { neuropathic pain } \\
\mathbf{( N = 4 0 )}\end{array}$ & $\begin{array}{l}\text { Patients with } \\
\text { definite } \\
\text { nociceptive pain } \\
\mathbf{( N = 3 9 )}\end{array}$ \\
\hline $\begin{array}{l}\text { General } \\
\text { activity }\end{array}$ & $4.6 \pm 2.6$ & $5.7 \pm 2.3^{\mathrm{a}}$ & $3.6 \pm 2.6$ \\
\hline $\begin{array}{l}\text { Mood } \\
\text { Walking }\end{array}$ & $4.0 \pm 3.1$ & $5.4 \pm 2.9^{\mathrm{a}}$ & $3.0 \pm 2.7$ \\
$\begin{array}{l}\text { ability } \\
\text { Normal } \\
\text { work }\end{array}$ & $5.0 \pm 3.2$ & $6.6 \pm 2.7^{\mathrm{a}}$ & $3.2 \pm 3.1$ \\
\hline \begin{tabular}{l} 
Relations \\
\hline Sleep
\end{tabular} & $3.4 \pm 3.3$ & $5.0 \pm 3.2^{\mathrm{a}}$ & $3.9 \pm 3.1$ \\
\hline $\begin{array}{l}\text { Enjoyment } \\
\text { of life }\end{array}$ & $3.7 \pm 3.3$ & $5.1 \pm 3.2^{\mathrm{a}}$ & $2.4 \pm 2.8$ \\
\hline
\end{tabular}

Abbreviation: $A D L=$ activity of daily living.

Values are given in mean \pm SD.

a $p<0.001, t$ test.

cases. There was no association between a depressive state $(\mathrm{BDI}>14)$ and age, sex, or disease duration. Univariate regression analyses revealed pain severity as well as walking and visual impairment to be associated with depressive state. In the multiple logistic regression analysis, pain intensity (OR $1.53[1.22-1.91], p<0.001)$ remained the only factor independently associated with a depressive state.

\section{Pain, Depression, and Walking Impairment Are 3 Main QoL Predictors}

The physical but not the mental composite subscale was significantly lower in pain sufferers (table 4). Among pain sufferers, patients with definite neuropathic pain had significantly lower scores in both SF-36 composites comparing to those with nociceptive pain. Multivariate regression analysis identified pain severity $(p<0.001)$ and walking impairment $(p<0.001)$ as 2 independent predictors explaining 53.9\% of the physical QoL composite variability. Depression measured by the BDI score $(p<0.001)$ and to a lesser extent walking impairment $(p=0.043)$ determined $39.7 \%$ of the mental QoL composite variability.

\section{Symptomatic Pain Treatment Is Insufficiently Effective in Real-Life Practice}

Two-thirds ( $\mathrm{n}=81,64.8 \%)$ of the 125 pain sufferers took pain medications, antidepressants, or both. Most of them took $1(\mathrm{n}=44,35.2 \%)$ or $2(\mathrm{n}=25,20.0 \%)$ pain medications. Nine patients $(7.2 \%)$ had 3 different pain medications, and 3 patients had 4, 5, and 6 medications each. Pain medication included nonopioid analgesics (including nonsteroidal anti-inflammatory drugs $)(\mathrm{n}=47,37.6 \%)$, antiepileptic medications for neuropathic pain (including gabapentin, pregabalin, carbamazepine, and oxcarbazepine)
( $\mathrm{n}=51,40.8 \%)$, and opioids $(\mathrm{n}=13,10.4 \%)$. Antidepressants were taken by $21(16.8 \%)$ pain sufferers. Surprisingly, only one-third $(\mathrm{n}=10,29.4 \%)$ of those with at least moderate depression $(\mathrm{BDI}>20)$ took antidepressants. Seven of 10 suffered from pain with a median pain intensity of 5.0 (2.0-8.0), so that antidepressant medication could be a component of pain therapy.

Patients with definite neuropathic pain took symptomatic therapy significantly more often compared with those with nociceptive pain ( $85.0 \%$ vs $51.3 \%, p=0.002$, table 5$)$. However, among the 40 patients with neuropathic pain, only 23 (57.5\%) took specific medications. Retrospectively, patients reported a substantial reduction of the pain intensity through pain medications; median 60\% (range 0-100) in all patients, $50 \%(0-100)$ in those with definite neuropathic pain, $65 \%$ $(0-100)$ in those with nociceptive pain. Only 4 patients (4.9\%) were pain-free, and 25 patients (30.9\%) reported mild pain. Most patients still reported moderate $(n=41,50.6 \%)$ or severe $(\mathrm{n}=11,13.6 \%)$ pain despite symptomatic treatment. Only $28.8 \%$ of those with spasticity-associated pain received antispastic medications.

\section{Effects of Immunotherapies on Pain Experience}

There was no difference in terms of pain prevalence or intensity in patients with different immunotherapies. Retrospectively, $39.5 \%$ of pain sufferers reported improvement of pain after start of immunotherapy: 28 of 75 (37.3\%) under rituximab, 6 of 15 (40.0\%) under azathioprine, 2 of 6 (33.3\%) under mycophenolate mofetil, and 6 of $9(66.7 \%)$ under tocilizumab.

\section{Pain Pattern Question Can Be an Effective Screening Tool}

Finally, we searched for a short screening question allowing identification of those patients most affected by pain in NMOSD. We used the 4 pain patterns from the PDQ (table 6). Patients suffering from pain attacks without painless intervals (patterns 2 and 4 ) had significantly more intense pains and a significantly lower physical QoL component. Moreover, the majority of those with pattern 4 suffered from moderate or severe depression (87.5\%) and neuropathic pain (62.5\%) and had lower mental QoL.

\section{Discussion}

We evaluated a large cohort of patients with AQP4IgG-seropositive NMOSD for pain and comorbid depression. As much as $75.3 \%$ of all patients suffered from NMOSD-associated chronic pain, in line with previously reported $80 \%-86 \%$ in smaller studies from other geographic areas. ${ }^{10-12,14,23}$ The majority of patients reported continuous pain, often superimposed by pain attacks. Pain localization was in the legs in 3/4 and around the trunk and in arms in $1 / 2$ each. Overall pain intensity was lower in our cohort compared with previous studies conducted a decade ago, ${ }^{10-12}$ and only $10 \%$ 
Table 4 Quality of Life in Patients With and Without NMOSD-Associated Pain

\begin{tabular}{|c|c|c|c|c|c|c|c|}
\hline $\begin{array}{l}\text { SF-36 } \\
\text { domain }\end{array}$ & $\begin{array}{l}\text { All patients } \\
(\mathrm{N}=166)\end{array}$ & $\begin{array}{l}\text { Patients } \\
\text { without pain }(\mathrm{N} \\
=41)\end{array}$ & $\begin{array}{l}\text { Patients with } \\
\text { pain }(N=125)\end{array}$ & $\begin{array}{l}\text { Patients with definite } \\
\text { nociceptive pain } \\
(\mathrm{N}=39)\end{array}$ & $\begin{array}{l}\text { Patients with definite } \\
\text { neuropathic pain } \\
(\mathrm{N}=40)\end{array}$ & $\begin{array}{l}\text { Patients } \\
\text { with BDI } \\
0-14 \\
(\mathrm{~N}=99)\end{array}$ & $\begin{array}{l}\text { Patients } \\
\text { with BDI } \\
>14 \\
(\mathrm{~N}=66)\end{array}$ \\
\hline $\begin{array}{l}\text { SF-36 } \\
\text { PF }\end{array}$ & $47.7 \pm 36.0$ & $63.3 \pm 39.1$ & $43.4 \pm 33.7^{\mathrm{a}}$ & $52.1 \pm 36.9$ & $36.1 \pm 28.6^{b}$ & $59.6 \pm 35.2$ & $30.7 \pm 29.5^{c}$ \\
\hline $\begin{array}{l}\text { SF-36 } \\
\text { RP }\end{array}$ & $41.0 \pm 41.3$ & $44.7 \pm 24.3$ & $36.9 \pm 38.8^{a}$ & $39.1 \pm 37.1$ & $28.9 \pm 38.7$ & $53.6 \pm 41.6$ & $22.2 \pm 33.0^{c}$ \\
\hline $\begin{array}{l}\text { SF-36 } \\
\text { BP }\end{array}$ & $52.2 \pm 30.1$ & $78.1 \pm 32.9$ & $44.7 \pm 24.3^{\mathrm{a}}$ & $54.1 \pm 23.6$ & $33.9 \pm 20.1^{b}$ & $59.9 \pm 27.2$ & $41.6 \pm 30.6^{c}$ \\
\hline $\begin{array}{l}\text { SF-36 } \\
\text { GH }\end{array}$ & $44.1 \pm 20.4$ & $51.7 \pm 19.5$ & $41.8 \pm 20.2^{\mathrm{a}}$ & $46.5 \pm 20.1$ & $36.6 \pm 15.8^{b}$ & $51.3 \pm 20.2$ & $33.1 \pm 15.3^{c}$ \\
\hline $\begin{array}{l}\text { SF-36 } \\
\text { VT }\end{array}$ & $43.1 \pm 21.9$ & $52.3 \pm 20.6$ & $40.3 \pm 21.7^{a}$ & $45.7 \pm 21.3$ & $31.2 \pm 18.7^{b}$ & $53.8 \pm 18.6$ & $27.0 \pm 15.8^{c}$ \\
\hline $\begin{array}{l}\text { SF-36 } \\
\text { SF }\end{array}$ & $66.6 \pm 29.7$ & $77.3 \pm 25.8$ & $63.6 \pm 30.1^{a}$ & $68.3 \pm 27.6$ & $57.8 \pm 30.2$ & $77.7 \pm 25.7$ & $50.5 \pm 27.5^{c}$ \\
\hline $\begin{array}{l}\text { SF-36 } \\
\text { RE }\end{array}$ & $68.5 \pm 42.0$ & $81.9 \pm 34.6$ & $65.3 \pm 43.0^{a}$ & $76.9 \pm 37.6$ & $52.1 \pm 45.8^{b}$ & $82.3 \pm 35.2$ & $47.9 \pm 43.2^{c}$ \\
\hline $\begin{array}{l}\text { SF-36 } \\
\text { MH }\end{array}$ & $65.5 \pm 20.9$ & $68.0 \pm 18.5$ & $64.7 \pm 21.7$ & $70.7 \pm 20.9$ & $56.7 \pm 24,3^{b}$ & $76.8 \pm 13.6$ & $48.6 \pm 18.5^{c}$ \\
\hline $\begin{array}{l}\text { SF-36 } \\
\text { PCS }\end{array}$ & $34.7 \pm 12.2$ & $43.9 \pm 12.5$ & $32.2 \pm 10.8^{a}$ & $34.4 \pm 10.9$ & $29.6 \pm 9.3^{b}$ & $38.1 \pm 12.0$ & $29.6 \pm 10.7^{c}$ \\
\hline $\begin{array}{l}\text { SF-36 } \\
\text { MCS }\end{array}$ & $48.0 \pm 11.6$ & $49.2 \pm 10.2$ & $47.6 \pm 12.0$ & $50.5 \pm 12.2$ & $43.1 \pm 11.6^{b}$ & $53.2 \pm 8.0$ & $40.0 \pm 11.6^{c}$ \\
\hline
\end{tabular}

Abbreviations: $\mathrm{BP}=$ bodily pain; $\mathrm{GH}=$ general health; $\mathrm{MCS}=$ mental component summary; $\mathrm{NMOSD}=$ neuromyelitis optica spectrum disorder; $\mathrm{PF}=$ physical functioning; $\mathrm{QOL}$ = quality of life; RE = role-emotional; RP = role-physical; SF = social functioning; SF-36 = short form 36 and its different domains; VT = vitality. Values are given in mean \pm SD.

a Significant lower comparing to patients without pain.

${ }^{\mathrm{b}}$ Significant lower comparing to patients with a nociceptive pain.

' Significant lower comparing to patients without a depressive state, $t$ test.

suffered from severe pain. Both median EDSS and the total number of involved spinal segments were lower than in previous studies. Less aggressive disease course, probably due to earlier diagnosis and/or more effective immunotherapy, could explain these differences. Indeed, two-thirds of our patients received rituximab, and about $40 \%$ reported reduction of pain under current immunotherapy. A positive selection bias could be another possible explanation. No data on questionnaire response rates have been reported in 2 of 3 abovementioned smaller surveys. ${ }^{11,12}$ Of interest, similar to one of the previous studies, we achieved a relative high response rate and pain severity was very similar in both studies $\left(3.6 \pm 2.8\right.$ other study; $3.8 \pm 2.1$ our cohort). ${ }^{10}$

Using the PDQ 24\% of our patients had definite neuropathic pain and further $26 \%$ signs of possible neuropathic pain. Two previous studies reported a significantly higher prevalence of neuropathic pain, $62 \%$ and $86 \%$, respectively, based on the Douleur Neuropathique 4 questionnaire and less clearly defined clinical criteria. ${ }^{12,23}$ In a recent PainDetect-based small study, definite neuropathic pain was present in $7 \%$ only. ${ }^{14}$

We were able to identify several predictors of pain in our cohort. The number of myelitis episodes and the extent of spinal cord lesions independently contributed to the risk of NMOSD-associated pain. Previous smaller studies demonstrated contradictory results. ${ }^{11,12,23}$ Although a correlation between pain intensity and an overall length of the spinal lesions was reported, this could not be confirmed in another study. ${ }^{11,12}$ It is likely that different severity and location (both sagittal and axial) of injuries have different effects on pain perception. In contrast to a recent UK study, ${ }^{23}$ we could not confirm a protective effect of persistent cervical lesions; however, injuries in the upper thoracic (but not cervical or lower thoracic) segments were critical for development of chronic pain. Previously, a causative relationship between upper thoracic lesions and neuropathic pain was postulated. ${ }^{23}$ As known, patients with spinal lesions develop both neuropathic and nociceptive pain. ${ }^{24}$ To evaluate a link between spinal lesions and neuropathic pain, we compared patients with a definite nociceptive and definite neuropathic pain. We could not confirm a specific association of the latter with any extent or any precise sagittal lesions location. In contrast, the number of involved upper thoracic segments was significantly associated with the risk of spasticity-associated pain, observed in two-thirds of pain sufferers. Spasticity was one of the main mechanisms underlying nociceptive NMOSD-associated pain in our cohort, being present in almost $90 \%$ of these patients.

Similar to previous studies, we found that approximately $20 \%$ of all respondents suffered from short-lasting PTSs. ${ }^{17}$ Despite a previously supported association of PTS to incompletely 
Table 5 Prevalence and Efficacy of Symptomatic Therapy in Pain Sufferers

\begin{tabular}{llll}
\hline & $\begin{array}{l}\text { All pain } \\
\text { sufferers } \\
\mathbf{( N = 1 2 5 )}\end{array}$ & $\begin{array}{l}\text { Patients with definite nociceptive pain } \\
\mathbf{( N = 3 9 )}\end{array}$ & $\begin{array}{l}\text { Patients with definite neuropathic pain } \\
(\mathbf{N}=\mathbf{4 0})\end{array}$ \\
\hline $\begin{array}{l}\text { Symptomatic therapy } \\
63.8 \%(81)\end{array}$ & $51.3 \%(20)$ & $85 \%(34)$ \\
\hline $\begin{array}{l}\text { Pain reduction by symptomatic } \\
\text { therapy in the last week (median, } \\
\text { min-max) }\end{array}$ & $60 \%(0-100)$ & $65 \%(0-100)$ & $50 \%(0-100)$ \\
\hline $\begin{array}{l}\text { Mean pain intensity } \\
\text { Pain-free }\end{array}$ & $4.3 \pm 2.0$ & $3.3 \pm 1.6$ & $5.0 \pm 2.0^{\mathrm{a}}$ \\
\hline Mild pain (1-3 NRS) & $4(4.9 \%)$ & $1(5.0 \%)$ & 0 \\
\hline Moderate pain (4-6 NRS) & $25(30.9 \%)$ & $10(50.0 \%)$ & $9(26.5 \%)$ \\
\hline Severe pain (>6 NRS) & $41(50.6 \%)$ & $9(45.0 \%)$ & $15(44.1 \%)$ \\
\hline
\end{tabular}

Abbreviation: NRS $=$ Numeric Rating Scale.

If not otherwise specified, values are given in mean \pm SD. Patients with ambiguous pain character (probable neuropathic or nociceptive) were excluded from this analysis.

a $p<0.001, t$ test.

remyelinated spinal lesions, we could not confirm this finding either. In MS, PTSs are supposed to be associated with thalamocortical lesions. ${ }^{25,26}$

The $19 \%$ prevalence of moderate to severe depression in our cohort was lower compared with an earlier reported $28 \%$ in NMOSD. ${ }^{27}$ Similar to previous studies, only pain severity but not disability, disease activity, or any other demographic parameter was associated with depression. Depression was the only factor associated with neuropathic but not nociceptive pain; however, identification of causative relationships between these conditions is impossible in a cross-sectional study. Bidirectional relationships between depression and neuropathic pain are well known and especially in inflammatory diseases share common underlying mechanisms. ${ }^{28}$ It is noteworthy that a specific direct link between NMOSD and depression has been supposed in experimental studies: AQP4 deficiency itself results in a decreased hippocampal neurogenesis, which could contribute to the pathogenesis of depression. ${ }^{29}$
Despite being mild to moderate, pain and depression can have enormous negative effects on patient's life. Pain markedly reduced all aspects of ADL. Pain intensity and walking impairment were 2 main factors independently associated with lower physical QoL, whereas the latter and depression had an impact on the mental QoL. Comparing patients with nociceptive and neuropathic pain, the latter had significantly lower $\mathrm{ADL}$ as well as both lower physical and mental composites of QoL. Of interest, 2 temporal pain patterns (persistent pain with pain attacks and pain attacks with pain between them) were associated with a markedly higher pain intensity, depression prevalence, and lower QoL. This simple image-based question allowing prompt identification of most disabled patients might be useful for pain screening in NMOSD.

In previous NMOSD studies, an insufficient symptomatic therapy has been reported. ${ }^{15}$ In our cohort, $65 \%$ received pain medications, and two-thirds of them reported a significant pain relief. Despite multiple medications, pain intensity mostly remained moderate, and only a minority of patients

Table 6 Association of 4 Pain Patterns With Pain Characteristics, Depression, and QoL

\begin{tabular}{|c|c|c|c|c|c|}
\hline Pain pattern & $\begin{array}{l}\text { Average pain } \\
\text { intensity }\end{array}$ & $\begin{array}{l}\text { Prevalence of definitive } \\
\text { neuropathic pain }\end{array}$ & $\begin{array}{l}\text { Prevalence of depression } \\
\text { (BDI > 14) }\end{array}$ & $\begin{array}{l}\text { Physical } \\
\text { QoL }\end{array}$ & $\begin{array}{l}\text { Mental } \\
\text { QoL }\end{array}$ \\
\hline $\begin{array}{l}\text { Continuous pain with slight } \\
\text { fluctuations }\end{array}$ & $3.9 \pm 2.0$ & $22.2 \%$ & $40.5 \%$ & $33.2 \pm 9.6$ & $\begin{array}{l}47.9 \pm \\
11.7\end{array}$ \\
\hline $\begin{array}{l}\text { Continuous pain with pain } \\
\text { attacks }\end{array}$ & $4.8 \pm 2.0^{a}$ & $35.5 \%$ & $43.8 \%$ & $27.9 \pm 9.3^{a}$ & $\begin{array}{l}48.7 \pm \\
10.9\end{array}$ \\
\hline $\begin{array}{l}\text { Pain attacks with painless } \\
\text { periods }\end{array}$ & $3.0 \pm 2.0$ & $35.4 \%$ & $33.3 \%$ & $34.0 \pm 11.1$ & $\begin{array}{l}47.9 \pm \\
12.4\end{array}$ \\
\hline $\begin{array}{l}\text { Pain attacks without painless } \\
\text { periods }\end{array}$ & $5.6 \pm 1.8^{a}$ & $62.5 \%^{\mathrm{b}}$ & $87.5 \%^{\mathrm{b}}$ & $24.9 \pm 9.8^{a}$ & $\begin{array}{l}38.6 \pm \\
13.4^{\mathrm{b}}\end{array}$ \\
\hline
\end{tabular}

Abbreviations: QOL = quality of life; BDI = Beck Depression Inventory II.

Values are given in mean \pm SD.

a Significant difference vs patterns 1 and 3; ANOVA

b Significant difference vs patterns 1, 2, and 3; ANOVA or Fisher exact test, respectively. 
was pain-free. Insufficient on-target medication could be one of the reasons: antispastic medications were administered in only $29 \%$ of those with a spasticity-associated pain and only $58 \%$ of patients with neuropathic pain had specific treatment.

Compared with pain, depression was less often adequately treated. Twenty-nine percent of those with moderate to severe depression received antidepressants. The actual number of patients receiving adequate antidepressant pharmacotherapy is probably even lower, as at least in some of them, antidepressants were administered as a part of pain therapy.

The strengths of our study are inclusion of a relatively large cohort of purely AQP4-IgG-seropositive NMOSD patients and the definition of clinical and paraclinical predictors of pain as well as its association with depression and effects on QoL. There are also limitations. Because we only asked for pharmacologic treatments, no information about nonpharmacologic pain therapies and psychotherapy is available. Transcutaneous electric nerve stimulation was recently reported to reduce persistent central neuropathic pain in NMOSD. ${ }^{30}$ Because MRI data were retrieved by record review, we could not perform a precise analysis of transverse localization and size of the spinal lesions. In addition, no brain MRI was performed to evaluate central nociceptive pathways. There were no sufficient data on lumbar MRI, rarely involved by seropositive NMOSD. The analysis of lesion extension in the acute phase of myelitis could be also promising, as some injured foci become invisible afterward. Moreover, prospective evaluation of the type and severity of pain in the first 6 months after acute myelitis could be helpful for precise analysis of possible underlying mechanisms. A relatively high proportion of pain sufferers (35\%) took no pain medications during the study. It remains unclear whether the medications have not been administered due to low pain intensity or stopped due to low efficacy and side effects. It would be important to address this point in further studies. Finally, we did not perform an analysis of fatigue, an important factor influencing depression and QoL.

In conclusion, chronic pain and depression are highly prevalent and strongly affect QoL and ADL in AQP4-IgG-seropositive NMOSD. Both conditions remain undertreated and therefore should be asked for in the diagnostic workup. Pain attacks without painless periods are typical for NMOSD and have the most severe impact. Episodes of myelitis involving upper thoracic segments are main drivers of pain in NMOSD and should be prevented and aggressively treated. Adequate immunotherapy has a beneficial effect on pain experience. Higher awareness and interventional studies on targeted symptomatic treatment of neuropathic and spasticity-associated pain, including characteristic and very intense short-lasting PTSs, are warranted and could change a real-life clinical practice in NMOSD.

\section{Acknowledgment}

I. Ayzenberg and I. Kleiter had full access to all the data in the study and take responsibility for the integrity of the data and the accuracy of the data analysis. The authors thank all patients for participating in the study.

\section{Study Funding}

The study was funded in part by an unrestricted educational grant from Chugai Ltd. Japan. The NEMOS cohort/ NationNMO is supported by the German Ministry for Education and Research (BMBF) as part of the German Competence Network Multiple Sclerosis (KKNMS; for NEMOS NationNMO-DAB FKZ 01GI1602C to J.-P. Stellmann, NationNMO-PAT FKZ 01GI1602B to O. Aktas, and NationNMO-LAB FKZ 01GI1602A to B. Wildemann).

\section{Disclosure}

I. Ayzenberg has received travel grants from Biogen Idec and the Guthy-Jackson Charitable Foundation, served on scientific advisory boards for Roche and Alexion, and received research support from Diamed, none related to this manuscript. D. Richter and E. Henke have no conflicts of interest. SA received travel grant from Celgene and speaker's honorary from Roche and Bayer. F. Paul serves as Academic Editor for PLoS One, Associate Editor for Neurology, Neuroimmunology \& Neuroinflammation, is a member of the Novartis OCTIMS study steering committee, MedImmune/Viela Bio steering committee; reports speaker honoraria and travel grants from Bayer, Novartis, Biogen Idec, Teva, Sanofi-Aventis/Genzyme, and Merck Serono, Alexion, Chugai, MedImmune, Shire, Roche, Actelion, Celgene and consultancies for Sanofi Genzyme, Biogen Idec, MedImmune, Shire, Alexion; received research support from Bayer, Novartis, Biogen Idec, Teva, Sanofi-Aventis/Genzyme, Alexion, and Merck Serono, German Research Council (DFG Exc 257), Werth Stiftung of the City of Cologne, German Ministry of Education and Research (BMBF Competence Network Multiple Sclerosis), Arthur Arnstein Stiftung Berlin, EU FP7 Framework Program (combims.eu), Arthur Arnstein Foundation Berlin, GuthyJackson Charitable Foundation, National Multiple Sclerosis Society of the USA. C. Trebst has received honoraria for consultation and expert testimony from Biogen Idec/GmbH, Genzyme $\mathrm{GmbH}$, Novartis Pharma GmbH, MERCK, Chugai Pharma Germany GmbH, and Roche Pharma GmbH. None of this interfered with the current report. M.W. Hümmert reports no disclosures. T. Kümpfel has received speaker honoraria including advisory boards from Bayer HealthCare, Teva Pharma, Merck, Novartis Pharma, Sanofi-Aventis/Genzyme, Roche Pharma, and Biogen as well as grant support from Novartis and Chugai Pharma in the past. J. Babla reports grants for OCT research from the Friedrich-Baur-Stiftung and Merck, personal fees and nonfinancial support from Alexion, Biogen, Celgene, Heidelberg Engineering, Merck, Novartis, Roche, Santhera, and Sanofi Genzyme, and nonfinancial support of the Guthy-Jackson Charitable Foundation, all outside the submitted work. J. Havla is (partially) funded by the German Federal Ministry of Education and Research (Grant Numbers 01ZZ1603[A-D] and 01ZZ1804[A-H] (DIFUTURE)). M. Ringelstein received speaker honoraria from Novartis, Bayer, Roche, Alexion, and Ipsen and travel reimbursement from Bayer Schering, Biogen Idec, Merz, Genzyme, Teva, Grifols, Roche, and Merck, none related to this study. O. Aktas has received personal fees from Alexion, Bayer HealthCare, Biogen, Celgene, Merck Serono, MedImmune, Novartis, Roche, 
Teva, and Zambon, outside of the submitted work. S. Jarius reports no conflicts of interest. B. Wildemann received grants from the German Ministry of Education and Research, German Research Foundation, Dietmar Hopp Foundation, Klaus Tschira Foundation; grants and personal fees from Merck, Novartis, and Sanofi Genzyme; and personal fees from Bayer, Biogen, Roche, and Teva, none related to this work. V. Häußler has no conflict of interest. J.-P. Stellmann receives research funding from Deutsche Forschungsgemeinschaft and reports a grant from Biogen that partially funded the submitted work. A further grant is reported from Genzyme outside the submitted work. J.-P. Stellmann also received travel support and personal fees from Alexion, Biogen, and Genzyme outside the submitted work. M. Senel has received consulting and/or speaker honoraria from Alexion, Bayer, Biogen, Merck, Roche, and Sanofi Genzyme. She has received travel funding from Celgene and Teva. She has received research funding from the Hertha-Nathorff-Program. L. Klotz received compensation for serving on scientific advisory boards (Alexion, Janssen, Novartis, Merck Serono, Sanofi Genzyme, and Roche); speaker honoraria and travel support (Biogen, Novartis, Merck Serono, Sanofi Genzyme, Roche, and Teva); and research support (Biogen Idec, Merck Serono, Novartis, and Sanofi Genzyme). H.L. Pellkofer received honoraria for lectures from Bayer HealthCare, Biogen Idec, and Teva Pharma and travel reimbursement from Novartis. M.S. Weber receives research support from the Deutsche Forschungsgemeinschaft (DFG; WE 3547/5-1) and from Novartis, Teva, Biogen Idec, Roche, Merck, and the ProFutura Programm of the Universitätsmedizin Göttingen. M.S. Weber is serving as an editor for PLoS One. He received travel funding and/or speaker honoraria from Biogen Idec, Merck Serono, Novartis, Roche, Teva, Bayer, and Genzyme. M. Pawlitzki received travel accommodation and meeting reimbursement from Novartis. P.S. Rommer has received honoraria for lectures or consultancy from Alexion, Almirall, Biogen, Merck, Novartis, Roche, Sandoz, and Sanofi Genzyme. He has received research grants from Amicus, Biogen, Merck, and Roche, none related to this manuscript. A. Berthele has received personal compensations, speaker honoraria, and funding for travel from Alexion, Bayer HealthCare, Biogen, Celgene, Merck Serono, Mylan, Novartis, Roche, Sanofi Genzyme, and Teva. K.D. Wernecke reports no disclosures. K. Hellwig received consultant and speaker honoraria and grant support from Bayer, Biogen, Merck, Novartis, Sanofi Genzyme, Roche, and Teva. R. Gold received speaker's and board honoraria from Baxter, Bayer Schering, Biogen Idec, CLB Behring, Genzyme, Merck Serono, Novartis, Stendhal, Talecris, and Teva. His department received grant support from Bayer Schering, Biogen Idec, Genzyme, Merck Serono, Novartis, and Teva, all not related to the content of this manuscript. I. Kleiter has received speaker honoraria and travel funding from Alexion, Bayer, Biogen, Novartis, Merck, Sanofi Genzyme, and Roche; speaker honoraria from Mylan; travel funding from the Guthy-Jackson Charitable Foundation; consulted for Alexion, Bayer, Biogen, Celgene, Chugai, IQVIA, Novartis, Merck, and Roche; and received research support from Chugai and Diamed. Go to Neurology.org/NN for full disclosures.

\section{Publication History}

Received by Neurology: Neuroimmunology \& Neuroinflammation November 18, 2020. Accepted in final form February 2, 2021.

Appendix 1 Authors

\begin{tabular}{|c|c|c|}
\hline Name & Location & Contribution \\
\hline $\begin{array}{l}\text { Ilya } \\
\text { Ayzenberg, } \\
\text { MD }\end{array}$ & $\begin{array}{l}\text { Ruhr-University } \\
\text { Bochum, Bochum, } \\
\text { Germany }\end{array}$ & $\begin{array}{l}\text { Drafting/revision of the } \\
\text { manuscript for content, } \\
\text { including medical writing for } \\
\text { content; major role in the } \\
\text { acquisition of data; study } \\
\text { concept or design; and analysis } \\
\text { or interpretation of data }\end{array}$ \\
\hline $\begin{array}{l}\text { Daniel } \\
\text { Richter, MD }\end{array}$ & $\begin{array}{l}\text { Ruhr-University } \\
\text { Bochum, Bochum, } \\
\text { Germany }\end{array}$ & $\begin{array}{l}\text { Drafting/revision of the } \\
\text { manuscript for content, } \\
\text { including medical writing for } \\
\text { content, and major role in the } \\
\text { acquisition of data }\end{array}$ \\
\hline $\begin{array}{l}\text { Eugenia } \\
\text { Henke, MD }\end{array}$ & $\begin{array}{l}\text { Ruhr-University } \\
\text { Bochum, Bochum, } \\
\text { Germany }\end{array}$ & $\begin{array}{l}\text { Drafting/revision of the } \\
\text { manuscript for content, } \\
\text { including medical writing for } \\
\text { content, and major role in the } \\
\text { acquisition of data }\end{array}$ \\
\hline
\end{tabular}

\begin{tabular}{|c|c|c|}
\hline $\begin{array}{l}\text { Susanna } \\
\text { Asseyer, MD }\end{array}$ & $\begin{array}{l}\text { Berlin Institute of } \\
\text { Health, Berlin, Germany }\end{array}$ & $\begin{array}{l}\text { Drafting/revision of the } \\
\text { manuscript for content, } \\
\text { including medical writing for } \\
\text { content; major role in the } \\
\text { acquisition of data; and } \\
\text { analysis or interpretation of } \\
\text { data }\end{array}$ \\
\hline $\begin{array}{l}\text { Friedemann } \\
\text { Paul, MD }\end{array}$ & $\begin{array}{l}\text { Berlin Institute of } \\
\text { Health, Berlin, Germany }\end{array}$ & $\begin{array}{l}\text { Drafting/revision of the } \\
\text { manuscript for content, } \\
\text { including medical writing for } \\
\text { content, and major role in the } \\
\text { acquisition of data }\end{array}$ \\
\hline $\begin{array}{l}\text { Corinna } \\
\text { Trebst, MD }\end{array}$ & $\begin{array}{l}\text { Hannover Medical } \\
\text { School, Hannover, } \\
\text { Germany }\end{array}$ & $\begin{array}{l}\text { Drafting/revision of the } \\
\text { manuscript for content, } \\
\text { including medical writing for } \\
\text { content, and major role in the } \\
\text { acquisition of data }\end{array}$ \\
\hline
\end{tabular}

\begin{tabular}{lll}
\hline Martin W. & Ludwig-Maximilians & Drafting/revision of the \\
Hümmert, & University Munich, & manuscript for content, \\
MD & Munich, Germany & $\begin{array}{l}\text { including medical writing for } \\
\text { content, and major role in the } \\
\end{array}$ \\
& acquisition of data
\end{tabular}

\begin{tabular}{lll}
\hline Joachim & Ludwig-Maximilians & Drafting/revision of the \\
Havla, MD & University Munich, & manuscript for content, \\
including medical writing for \\
Munich, Germany & $\begin{array}{l}\text { content, and major role in the } \\
\text { acquisition of data }\end{array}$ \\
& & \\
\hline
\end{tabular}

\begin{tabular}{lll}
\hline Tania & Ludwig-Maximilians & Drafting/revision of the \\
Kümpfel, & University Munich, & manuscript for content, \\
MD & Munich, Germany & $\begin{array}{l}\text { including medical writing for } \\
\text { content, and major role in the } \\
\end{array}$ \\
& acquisition of data
\end{tabular}

\begin{tabular}{ll}
\hline Marius & Heinrich Heine \\
Ringelstein, & University Düsseldorf, \\
MD & Düsseldorf, Germany
\end{tabular}

Drafting/revision of the manuscript for content, including medical writing for content, and major role in the acquisition of data

\begin{tabular}{lll}
\hline Orhan & Heinrich Heine & Drafting/revision of the \\
Aktas, MD & University Düsseldorf, & manuscript for content, \\
Düsseldorf, Germany & $\begin{array}{l}\text { including medical writing } \\
\text { for content, and major role } \\
\text { in the acquisition of data }\end{array}$ \\
& & \\
\end{tabular}


Appendix 1 (continued)

\begin{tabular}{|c|c|c|}
\hline Name & Location & Contribution \\
\hline $\begin{array}{l}\text { Brigitte } \\
\text { Wildemann, } \\
\text { MD }\end{array}$ & $\begin{array}{l}\text { University of } \\
\text { Heidelberg, Heidelberg, } \\
\text { Germany; }\end{array}$ & $\begin{array}{l}\text { Drafting/revision of the } \\
\text { manuscript for content, } \\
\text { including medical writing } \\
\text { for content, and major role } \\
\text { in the acquisition of data }\end{array}$ \\
\hline $\begin{array}{l}\text { Sven Jarius, } \\
\text { MD }\end{array}$ & $\begin{array}{l}\text { University of } \\
\text { Heidelberg, Heidelberg, } \\
\text { Germany }\end{array}$ & $\begin{array}{l}\text { Drafting/revision of the } \\
\text { manuscript for content, } \\
\text { including medical writing for } \\
\text { content, and major role in the } \\
\text { acquisition of data }\end{array}$ \\
\hline $\begin{array}{l}\text { Vivien } \\
\text { Häußler, MD }\end{array}$ & $\begin{array}{l}\text { Zentrum für Molekulare } \\
\text { Neurobiologie, } \\
\text { Hamburg, Germany }\end{array}$ & $\begin{array}{l}\text { Drafting/revision of the } \\
\text { manuscript for content, } \\
\text { including medical writing for } \\
\text { content, and major role in the } \\
\text { acquisition of data }\end{array}$ \\
\hline $\begin{array}{l}\text { Jan-Patrick } \\
\text { Stellmann, } \\
\text { MD }\end{array}$ & $\begin{array}{l}\text { Zentrum für Molekulare } \\
\text { Neurobiologie, } \\
\text { Hamburg, Germany }\end{array}$ & $\begin{array}{l}\text { Drafting/revision of the } \\
\text { manuscript for content, } \\
\text { including medical writing } \\
\text { for content, and major role } \\
\text { in the acquisition of data }\end{array}$ \\
\hline $\begin{array}{l}\text { Makbule } \\
\text { Senel, MD }\end{array}$ & $\begin{array}{l}\text { University of Ulm, Ulm, } \\
\text { Germany }\end{array}$ & $\begin{array}{l}\text { Drafting/revision of the } \\
\text { manuscript for content, } \\
\text { including medical writing } \\
\text { for content, and major role } \\
\text { in the acquisition of data }\end{array}$ \\
\hline
\end{tabular}

\begin{tabular}{ll}
\hline Luisa Klotz, & University Hospital \\
MD & Münster, Münster, \\
& Germany
\end{tabular}

Drafting/revision of the manuscript for content, including medical writing for content, and major role in the acquisition of data

\begin{tabular}{lll}
\hline $\begin{array}{l}\text { Hannah L. } \\
\text { Pellkofer, } \\
\text { MD }\end{array}$ & $\begin{array}{l}\text { Ludwig-Maximilians } \\
\text { University Munich, } \\
\text { Munich, Germany }\end{array}$ & $\begin{array}{l}\text { Drafting/revision of the } \\
\text { manuscript for content, } \\
\text { including medical writing for } \\
\text { content, and major role in the } \\
\text { acquisition of data }\end{array}$ \\
\hline $\begin{array}{l}\text { Martin S. } \\
\text { Weber, MD }\end{array}$ & $\begin{array}{l}\text { University Medical } \\
\text { Center, Göttingen, }\end{array}$ & $\begin{array}{l}\text { Drafting/revision of the } \\
\text { manuscript for content, } \\
\text { including medical writing for } \\
\text { content, and major role in the } \\
\text { acquisition of data }\end{array}$ \\
& &
\end{tabular}

\begin{tabular}{lll}
\hline Marc & University Hospital & Drafting/revision of the \\
Pawlitzki, & Münster, Germany & manuscript for content, \\
MD & & including medical writing for \\
& content, and major role in the \\
& acquisition of data
\end{tabular}

\begin{tabular}{ll}
\hline Paulus S. & Medical University of \\
Rommer, & Vienna, Vienna, Austria \\
MD &
\end{tabular}

Drafting/revision of the manuscript for content, including medical writing for content, and major role in the acquisition of data

\begin{tabular}{lll}
\hline $\begin{array}{l}\text { Achim } \\
\text { Berthele, } \\
\text { MD }\end{array}$ & $\begin{array}{l}\text { Technical University of } \\
\text { Munich, Munich, } \\
\text { Germany }\end{array}$ & $\begin{array}{l}\text { Drafting/revision of the } \\
\text { manuscript for content, } \\
\text { including medical writing for } \\
\text { content, and major role in the } \\
\text { acquisition of data }\end{array}$ \\
$\begin{array}{l}\text { Klaus-Dieter } \\
\text { Wernecke, } \\
\text { MD }\end{array}$ & $\begin{array}{l}\text { CRO SOSTANA GmbH } \\
\text { Berlin, Germany }\end{array}$ & $\begin{array}{l}\text { Drafting/revision of the } \\
\text { manuscript for content, } \\
\text { including medical writing for } \\
\text { content, and analysis or } \\
\text { interpretation of data }\end{array}$ \\
\hline
\end{tabular}

Appendix 1 (continued)

\begin{tabular}{lll}
\hline Name & Location & Contribution \\
\hline $\begin{array}{l}\text { Kerstin } \\
\text { Hellwig, MD }\end{array}$ & $\begin{array}{l}\text { Ruhr-University } \\
\text { Bochum, Bochum, } \\
\text { Germany }\end{array}$ & $\begin{array}{l}\text { Drafting/revision of the } \\
\text { manuscript for content, } \\
\text { including medical writing for } \\
\text { content, and major role in the } \\
\text { acquisition of data }\end{array}$ \\
\hline $\begin{array}{l}\text { Ralf Gold, } \\
\text { MD }\end{array}$ & $\begin{array}{l}\text { Ruhr-University } \\
\text { Bochum, Bochum, } \\
\text { Germany }\end{array}$ & $\begin{array}{l}\text { Drafting/revision of the } \\
\text { manuscript for content, } \\
\text { including medical writing for } \\
\text { content, and major role in the } \\
\text { acquisition of data }\end{array}$ \\
\hline Ingo Kleiter, \\
MD & $\begin{array}{l}\text { Ruhr-University } \\
\text { Bochum, Bochum, } \\
\text { Germany }\end{array}$ & $\begin{array}{l}\text { Drafting/revision of the } \\
\text { manuscript for content, } \\
\text { including medical writing for } \\
\text { content; major role in the } \\
\text { acquisition of data; study } \\
\text { concept or design; and } \\
\text { analysis or interpretation of } \\
\text { data }\end{array}$ \\
& &
\end{tabular}

Appendix 2 Coinvestigators

Members of the Neuromyelitis Optica Study Group (NEMOS) are listed below in alphabetical order.

\begin{tabular}{|c|c|c|c|}
\hline Name & Location & Role & Contribution \\
\hline $\begin{array}{l}\text { Philipp } \\
\text { Albrecht }\end{array}$ & $\begin{array}{l}\text { Heinrich Heine } \\
\text { University, } \\
\text { Düsseldorf, Germany }\end{array}$ & $\begin{array}{l}\text { Co- } \\
\text { investigator }\end{array}$ & $\begin{array}{l}\text { Organizational } \\
\text { Support }\end{array}$ \\
\hline $\begin{array}{l}\text { Klemens } \\
\text { Angstwurm, } \\
\text { MD }\end{array}$ & $\begin{array}{l}\text { University Hospital, } \\
\text { Regensburg, } \\
\text { Germany }\end{array}$ & $\begin{array}{l}\text { Co- } \\
\text { investigator }\end{array}$ & $\begin{array}{l}\text { Organizational } \\
\text { Support }\end{array}$ \\
\hline $\begin{array}{l}\text { Antonios } \\
\text { Bayas, MD }\end{array}$ & $\begin{array}{l}\text { University Hospital, } \\
\text { Augsburg, Germany }\end{array}$ & $\begin{array}{l}\text { Co- } \\
\text { investigator }\end{array}$ & $\begin{array}{l}\text { Organizational } \\
\text { Support }\end{array}$ \\
\hline $\begin{array}{l}\text { Judith } \\
\text { Bellmann- } \\
\text { Strobl, MD }\end{array}$ & $\begin{array}{l}\text { Charité- } \\
\text { Universitätsmedizin } \\
\text { Berlin, Germany }\end{array}$ & $\begin{array}{l}\text { Co- } \\
\text { investigator }\end{array}$ & $\begin{array}{l}\text { Organizational } \\
\text { Support }\end{array}$ \\
\hline $\begin{array}{l}\text { Felix Bischof, } \\
\text { MD }\end{array}$ & $\begin{array}{l}\text { University Hospital, } \\
\text { Tübingen, Germany }\end{array}$ & $\begin{array}{l}\text { Co- } \\
\text { investigator }\end{array}$ & $\begin{array}{l}\text { Organizational } \\
\text { Support }\end{array}$ \\
\hline $\begin{array}{l}\text { Stefan } \\
\text { Bittner, MD }\end{array}$ & $\begin{array}{l}\text { University Medical } \\
\text { Center of the } \\
\text { Johannes Gutenberg } \\
\text { University, Mainz, } \\
\text { Germany }\end{array}$ & $\begin{array}{l}\text { Co- } \\
\text { investigator }\end{array}$ & $\begin{array}{l}\text { Organizational } \\
\text { Support }\end{array}$ \\
\hline $\begin{array}{l}\text { Tobias } \\
\text { Böttcher, MD }\end{array}$ & $\begin{array}{l}\text { Johanna-Odebrecht- } \\
\text { Stiftung, Greifswald, } \\
\text { Germany }\end{array}$ & $\begin{array}{l}\text { Co- } \\
\text { investigator }\end{array}$ & $\begin{array}{l}\text { Organizational } \\
\text { Support }\end{array}$ \\
\hline $\begin{array}{l}\text { Buttmann } \\
\text { Mathias, MD }\end{array}$ & $\begin{array}{l}\text { University of } \\
\text { Würzburg, Germany }\end{array}$ & $\begin{array}{l}\text { Co- } \\
\text { investigator }\end{array}$ & $\begin{array}{l}\text { Organizational } \\
\text { Support }\end{array}$ \\
\hline $\begin{array}{l}\text { Ankelien } \\
\text { Duchow }\end{array}$ & $\begin{array}{l}\text { Universitätsmedizin } \\
\text { Berlin, Germany }\end{array}$ & $\begin{array}{l}\text { Co- } \\
\text { investigator }\end{array}$ & $\begin{array}{l}\text { Organizational } \\
\text { Support }\end{array}$ \\
\hline $\begin{array}{l}\text { Barbara } \\
\text { Ettrich, MD }\end{array}$ & $\begin{array}{l}\text { University Hospital, } \\
\text { Leipzig, Germany }\end{array}$ & $\begin{array}{l}\text { Co- } \\
\text { investigator }\end{array}$ & $\begin{array}{l}\text { Organizational } \\
\text { Support }\end{array}$ \\
\hline $\begin{array}{l}\text { Jürgen Faiss, } \\
\text { MD }\end{array}$ & $\begin{array}{l}\text { Asklepios Klinik, } \\
\text { Teupitz, Germany }\end{array}$ & $\begin{array}{l}\text { Co- } \\
\text { investigator }\end{array}$ & $\begin{array}{l}\text { Organizational } \\
\text { Support }\end{array}$ \\
\hline
\end{tabular}


Appendix 2 (continued)

Members of the Neuromyelitis Optica Study Group (NEMOS) are listed below in alphabetical order.

\begin{tabular}{|c|c|c|c|c|c|c|c|}
\hline Name & Location & Role & Contribution & Name & Location & Role & Contribution \\
\hline $\begin{array}{l}\text { Benedikt } \\
\text { Frank, MD }\end{array}$ & $\begin{array}{l}\text { University Hospital, } \\
\text { Essen, Germany }\end{array}$ & $\begin{array}{l}\text { Co- } \\
\text { investigator }\end{array}$ & $\begin{array}{l}\text { Organizational } \\
\text { Support }\end{array}$ & $\begin{array}{l}\text { Markus } \\
\text { Kraemer }\end{array}$ & $\begin{array}{l}\text { Alfried-Krupp- } \\
\text { Krankenhaus, Essen, } \\
\text { Germany }\end{array}$ & $\begin{array}{l}\text { Co- } \\
\text { investigator }\end{array}$ & $\begin{array}{l}\text { Organizational } \\
\text { Support }\end{array}$ \\
\hline $\begin{array}{l}\text { Anna Gahlen, } \\
\text { MD }\end{array}$ & $\begin{array}{l}\text { Ruhr-University } \\
\text { Bochum, Germany }\end{array}$ & $\begin{array}{l}\text { Co- } \\
\text { investigator }\end{array}$ & $\begin{array}{l}\text { Organizational } \\
\text { Support }\end{array}$ & \multirow{2}{*}{$\begin{array}{l}\text { Markus } \\
\text { Krumbholz, } \\
\text { MD }\end{array}$} & \multirow[t]{2}{*}{$\begin{array}{l}\text { University Hospital, } \\
\text { Tübingen, Germany }\end{array}$} & \multirow[t]{2}{*}{$\begin{array}{l}\text { Co- } \\
\text { investigator }\end{array}$} & \multirow[t]{2}{*}{$\begin{array}{l}\text { Organizational } \\
\text { Support }\end{array}$} \\
\hline $\begin{array}{l}\text { Achim Gass, } \\
\text { MD }\end{array}$ & $\begin{array}{l}\text { University Hospital, } \\
\text { Mannheim, Germany }\end{array}$ & $\begin{array}{l}\text { Co- } \\
\text { investigator }\end{array}$ & $\begin{array}{l}\text { Organizational } \\
\text { Support }\end{array}$ & & & & \\
\hline Christian Geis & $\begin{array}{l}\text { Department of } \\
\text { Neurology, Jena } \\
\text { University Hospital }\end{array}$ & $\begin{array}{l}\text { Co- } \\
\text { investigator }\end{array}$ & $\begin{array}{l}\text { Organizational } \\
\text { Support }\end{array}$ & $\begin{array}{l}\text { Stefan Langel, } \\
\text { MD }\end{array}$ & $\begin{array}{l}\text { Landeskrankenhaus } \\
\text { Rheinhessen, } \\
\text { Germany }\end{array}$ & $\begin{array}{l}\text { Co- } \\
\text { investigator }\end{array}$ & $\begin{array}{l}\text { Organizational } \\
\text { Support }\end{array}$ \\
\hline & Germany & & & $\begin{array}{l}\text { Martin } \\
\text { Liebetrau, MD }\end{array}$ & $\begin{array}{l}\text { St. Josefs-Hospital, } \\
\text { Wiesbaden, Germany }\end{array}$ & $\begin{array}{l}\text { Co- } \\
\text { investigator }\end{array}$ & $\begin{array}{l}\text { Organizational } \\
\text { Support }\end{array}$ \\
\hline $\begin{array}{l}\text { Matthias } \\
\text { Grothe, MD }\end{array}$ & $\begin{array}{l}\text { University Hospital, } \\
\text { Greifswald, Germany }\end{array}$ & $\begin{array}{l}\text { Co- } \\
\text { investigator }\end{array}$ & $\begin{array}{l}\text { Organizational } \\
\text { Support }\end{array}$ & \multirow[t]{2}{*}{$\begin{array}{l}\text { Ralf Linker, } \\
\text { MD }\end{array}$} & \multirow{2}{*}{$\begin{array}{l}\text { University Hospital, } \\
\text { Regensburg, } \\
\text { Germany }\end{array}$} & \multirow[t]{2}{*}{$\begin{array}{l}\text { Co- } \\
\text { investigator }\end{array}$} & \multirow[t]{2}{*}{$\begin{array}{l}\text { Organizational } \\
\text { Support }\end{array}$} \\
\hline $\begin{array}{l}\text { Kerstin } \\
\text { Guthke, MD }\end{array}$ & $\begin{array}{l}\text { Klinikum Görlitz, } \\
\text { Germany }\end{array}$ & $\begin{array}{l}\text { Co- } \\
\text { investigator }\end{array}$ & $\begin{array}{l}\text { Organizational } \\
\text { Support }\end{array}$ & & & & \\
\hline $\begin{array}{l}\text { Axel } \\
\text { Haarmann, } \\
\text { MD }\end{array}$ & $\begin{array}{l}\text { University of } \\
\text { Würzburg, Germany }\end{array}$ & $\begin{array}{l}\text { Co- } \\
\text { investigator }\end{array}$ & $\begin{array}{l}\text { Organizational } \\
\text { Support }\end{array}$ & $\begin{array}{l}\text { De-Hyung } \\
\text { Lee, MD }\end{array}$ & $\begin{array}{l}\text { University Hospital, } \\
\text { Regensburg, } \\
\text { Germany }\end{array}$ & $\begin{array}{l}\text { Co- } \\
\text { investigator }\end{array}$ & $\begin{array}{l}\text { Organizational } \\
\text { Support }\end{array}$ \\
\hline $\begin{array}{l}\text { Hans-Peter } \\
\text { Hartung, MD }\end{array}$ & $\begin{array}{l}\text { Heinrich Heine } \\
\text { University, } \\
\text { Düsseldorf, Germany }\end{array}$ & $\begin{array}{l}\text { Co- } \\
\text { investigator }\end{array}$ & $\begin{array}{l}\text { Organizational } \\
\text { Support }\end{array}$ & $\begin{array}{l}\text { Felix Luessi, } \\
\text { MD }\end{array}$ & $\begin{array}{l}\text { University Medical } \\
\text { Center of the } \\
\text { Johannes Gutenberg } \\
\text { University, Mainz, } \\
\text { Germany }\end{array}$ & $\begin{array}{l}\text { Co- } \\
\text { investigator }\end{array}$ & $\begin{array}{l}\text { Organizational } \\
\text { Support }\end{array}$ \\
\hline $\begin{array}{l}\text { Bernhard } \\
\text { Hemmer, MD }\end{array}$ & $\begin{array}{l}\text { Technical University, } \\
\text { Munich, Germany }\end{array}$ & $\begin{array}{l}\text { Co- } \\
\text { investigator }\end{array}$ & $\begin{array}{l}\text { Organizational } \\
\text { Support }\end{array}$ & $\begin{array}{l}\text { Martin } \\
\text { Marziniak, } \\
\text { MD }\end{array}$ & $\begin{array}{l}\text { Isar-Amper Klinik Ost, } \\
\text { Munich, Germany }\end{array}$ & $\begin{array}{l}\text { Co- } \\
\text { investigator }\end{array}$ & $\begin{array}{l}\text { Organizational } \\
\text { Support }\end{array}$ \\
\hline $\begin{array}{l}\text { MD } \\
\text { Olaf } \\
\text { Hoffmann, } \\
\text { MD }\end{array}$ & $\begin{array}{l}\text { St. Josefs- } \\
\text { Krankenhaus, } \\
\text { Potsdam, Germany }\end{array}$ & $\begin{array}{l}\text { Co- } \\
\text { investigator }\end{array}$ & $\begin{array}{l}\text { Organizational } \\
\text { Support }\end{array}$ & $\begin{array}{l}\text { Christoph } \\
\text { Mayer, MD }\end{array}$ & $\begin{array}{l}\text { Neurologischen } \\
\text { Gemeinschaftspraxis } \\
\text { im Bienenkorbhaus, } \\
\text { Frankfurt, Germany }\end{array}$ & $\begin{array}{l}\text { Co- } \\
\text { investigator }\end{array}$ & $\begin{array}{l}\text { Organizational } \\
\text { Support }\end{array}$ \\
\hline $\begin{array}{l}\text { Ulrich } \\
\text { Hofstadt-van }\end{array}$ & $\begin{array}{l}\text { Klinikum Westfalen, } \\
\text { Dortmund Germany }\end{array}$ & $\begin{array}{l}\text { Co- } \\
\text { investigator }\end{array}$ & Organizational & $\begin{array}{l}\text { Stefanie } \\
\text { Meister, MD }\end{array}$ & $\begin{array}{l}\text { University Hospital, } \\
\text { Rostock, Germany }\end{array}$ & $\begin{array}{l}\text { Co- } \\
\text { investigator }\end{array}$ & $\begin{array}{l}\text { Organizational } \\
\text { Support }\end{array}$ \\
\hline Oy, MD & & & & $\begin{array}{l}\text { Arthur } \\
\text { Melms, MD }\end{array}$ & $\begin{array}{l}\text { Facharztpraxis für } \\
\text { Neurologie und }\end{array}$ & $\begin{array}{l}\text { Co- } \\
\text { investigator }\end{array}$ & $\begin{array}{l}\text { Organizational } \\
\text { Support }\end{array}$ \\
\hline $\begin{array}{l}\text { Jutta } \\
\text { Junghans, MD }\end{array}$ & $\begin{array}{l}\text { Krankenhaus Martha- } \\
\text { Maria, Halle, } \\
\text { Germany }\end{array}$ & $\begin{array}{l}\text { Co- } \\
\text { investigator }\end{array}$ & $\begin{array}{l}\text { Organizational } \\
\text { Support }\end{array}$ & & $\begin{array}{l}\text { Psychiatrie, Stuttgart, } \\
\text { Germany }\end{array}$ & & \\
\hline $\begin{array}{l}\text { Matthias } \\
\text { Kaste, MD }\end{array}$ & $\begin{array}{l}\text { Nordwest Hospital } \\
\text { Sanderbusch, Sande, }\end{array}$ & $\begin{array}{l}\text { Co- } \\
\text { investigator }\end{array}$ & $\begin{array}{l}\text { Organizational } \\
\text { Support }\end{array}$ & $\begin{array}{l}\text { Imke Metz, } \\
\text { MD }\end{array}$ & $\begin{array}{l}\text { University Hospital, } \\
\text { Göttingen, Germany }\end{array}$ & $\begin{array}{l}\text { Co- } \\
\text { investigator }\end{array}$ & $\begin{array}{l}\text { Organizational } \\
\text { Support }\end{array}$ \\
\hline & Germany & & & $\begin{array}{l}\text { Oliver } \\
\text { Neuhaus, MD }\end{array}$ & $\begin{array}{l}\text { SRH Krankenhaus, } \\
\text { Sigmaringen, }\end{array}$ & $\begin{array}{l}\text { Co- } \\
\text { investigator }\end{array}$ & $\begin{array}{l}\text { Organizational } \\
\text { Support }\end{array}$ \\
\hline $\begin{array}{l}\text { Barbara } \\
\text { Kaulen, MD }\end{array}$ & $\begin{array}{l}\text { University Hospital, } \\
\text { Hamburg, Germany }\end{array}$ & $\begin{array}{l}\text { Co- } \\
\text { investigator }\end{array}$ & $\begin{array}{l}\text { Organizational } \\
\text { Sunport }\end{array}$ & & Germany & & \\
\hline $\begin{array}{l}\text { Peter Kern, } \\
\text { MD }\end{array}$ & Asklepios Klinik, & Co- & Organizational & $\begin{array}{l}\text { Sabine } \\
\text { Niehaus, MD }\end{array}$ & $\begin{array}{l}\text { Klinikum Dortmund, } \\
\text { Germany }\end{array}$ & $\begin{array}{l}\text { Co- } \\
\text { investigator }\end{array}$ & $\begin{array}{l}\text { Organizational } \\
\text { Support }\end{array}$ \\
\hline $\begin{array}{l}\text { Pawel } \\
\text { Kermer, MD }\end{array}$ & $\begin{array}{l}\text { Nordwest Hospital } \\
\text { Sanderbusch, Sande, } \\
\text { Germany }\end{array}$ & $\begin{array}{l}\text { Co- } \\
\text { investigator }\end{array}$ & $\begin{array}{l}\text { Organizational } \\
\text { Support }\end{array}$ & $\begin{array}{l}\text { Florence } \\
\text { Pache, MD }\end{array}$ & $\begin{array}{l}\text { Charité University } \\
\text { Medicine, Berlin, } \\
\text { Germany }\end{array}$ & $\begin{array}{l}\text { Co- } \\
\text { investigator }\end{array}$ & $\begin{array}{l}\text { Organizational } \\
\text { Support }\end{array}$ \\
\hline $\begin{array}{l}\text { Christoph } \\
\text { Kleinschnitz, } \\
\text { MD }\end{array}$ & $\begin{array}{l}\text { University Hospital, } \\
\text { Essen, Germany }\end{array}$ & $\begin{array}{l}\text { Co- } \\
\text { investigator }\end{array}$ & $\begin{array}{l}\text { Organizational } \\
\text { Support }\end{array}$ & $\begin{array}{l}\text { Hans-Ulrich } \\
\text { Puhlmann, } \\
\text { MD }\end{array}$ & $\begin{array}{l}\text { Schlosspark-Klinik, } \\
\text { Berlin, Germany }\end{array}$ & $\begin{array}{l}\text { Co- } \\
\text { investigator }\end{array}$ & $\begin{array}{l}\text { Organizational } \\
\text { Support }\end{array}$ \\
\hline $\begin{array}{l}\text { Wolfgang } \\
\text { Köhler, MD }\end{array}$ & $\begin{array}{l}\text { University Hospital, } \\
\text { Leipzig, Germany }\end{array}$ & $\begin{array}{l}\text { Co- } \\
\text { investigator }\end{array}$ & $\begin{array}{l}\text { Organizational } \\
\text { Support }\end{array}$ & Refik Pul, MD & $\begin{array}{l}\text { University Hospital, } \\
\text { Essen, Germany }\end{array}$ & $\begin{array}{l}\text { Co- } \\
\text { investigator }\end{array}$ & $\begin{array}{l}\text { Organizational } \\
\text { Support }\end{array}$ \\
\hline $\begin{array}{l}\text { Markus } \\
\text { Kowarik, MD }\end{array}$ & $\begin{array}{l}\text { University Hospital, } \\
\text { Tübingen, Germany }\end{array}$ & $\begin{array}{l}\text { Co- } \\
\text { investigator }\end{array}$ & $\begin{array}{l}\text { Organizational } \\
\text { Support }\end{array}$ & $\begin{array}{l}\text { Paulus } \\
\text { Rommer, MD }\end{array}$ & $\begin{array}{l}\text { Medical University of } \\
\text { Wien, Austria }\end{array}$ & $\begin{array}{l}\text { Co- } \\
\text { investigator }\end{array}$ & $\begin{array}{l}\text { Organizational } \\
\text { Support }\end{array}$ \\
\hline
\end{tabular}

Appendix 2 (continued)

Members of the Neuromyelitis Optica Study Group (NEMOS) are listed below in alphabetical order. 
Appendix 2 (continued)

Members of the Neuromyelitis Optica Study Group (NEMOS) are listed below in alphabetical order.

\begin{tabular}{|c|c|c|c|}
\hline Name & Location & Role & Contribution \\
\hline $\begin{array}{l}\text { Kevin } \\
\text { Rostásy, MD }\end{array}$ & $\begin{array}{l}\text { Vestische Caritas- } \\
\text { Kliniken GmbH, } \\
\text { Datteln, Germany }\end{array}$ & $\begin{array}{l}\text { Co- } \\
\text { investigator }\end{array}$ & $\begin{array}{l}\text { Organizational } \\
\text { Support }\end{array}$ \\
\hline $\begin{array}{l}\text { Lioba } \\
\text { Rückriem, MD }\end{array}$ & $\begin{array}{l}\text { MediClin Hedon- } \\
\text { Klinik, Lingen (Ems), } \\
\text { Germany }\end{array}$ & $\begin{array}{l}\text { Co- } \\
\text { investigator }\end{array}$ & $\begin{array}{l}\text { Organizational } \\
\text { Support }\end{array}$ \\
\hline $\begin{array}{l}\text { Klemens } \\
\text { Ruprecht, MD }\end{array}$ & $\begin{array}{l}\text { Charité } \\
\text {-Universitätsmedizin } \\
\text { Berlin, Germany }\end{array}$ & $\begin{array}{l}\text { Co- } \\
\text { investigator }\end{array}$ & $\begin{array}{l}\text { Organizational } \\
\text { Support }\end{array}$ \\
\hline $\begin{array}{l}\text { Christoph } \\
\text { Ruschil, MD }\end{array}$ & $\begin{array}{l}\text { University Hospital, } \\
\text { Tübingen, Germany }\end{array}$ & $\begin{array}{l}\text { Co- } \\
\text { investigator }\end{array}$ & $\begin{array}{l}\text { Organizational } \\
\text { Support }\end{array}$ \\
\hline $\begin{array}{l}\text { Sven } \\
\text { Schippling, } \\
\text { MD }\end{array}$ & $\begin{array}{l}\text { University Hospital, } \\
\text { Zürich, Switzerland }\end{array}$ & $\begin{array}{l}\text { Co- } \\
\text { investigator }\end{array}$ & $\begin{array}{l}\text { Organizational } \\
\text { Support }\end{array}$ \\
\hline $\begin{array}{l}\text { Matthias } \\
\text { Schwab, MD }\end{array}$ & $\begin{array}{l}\text { University Hospital, } \\
\text { Jena, Germany }\end{array}$ & $\begin{array}{l}\text { Co- } \\
\text { investigator }\end{array}$ & $\begin{array}{l}\text { Organizational } \\
\text { Support }\end{array}$ \\
\hline $\begin{array}{l}\text { Jörn Peter } \\
\text { Sieb, MD }\end{array}$ & $\begin{array}{l}\text { Helios } \\
\text { Hanseklinikum, } \\
\text { Stralsund, Germany }\end{array}$ & $\begin{array}{l}\text { Co- } \\
\text { investigator }\end{array}$ & $\begin{array}{l}\text { Organizational } \\
\text { Support }\end{array}$ \\
\hline $\begin{array}{l}\text { Nadja Siebert, } \\
\text { MD }\end{array}$ & $\begin{array}{l}\text { Charité- } \\
\text { Universitätsmedizin } \\
\text { Berlin, Germany }\end{array}$ & $\begin{array}{l}\text { Co- } \\
\text { investigator }\end{array}$ & $\begin{array}{l}\text { Organizational } \\
\text { Support }\end{array}$ \\
\hline $\begin{array}{l}\text { Claudia } \\
\text { Sommer, MD }\end{array}$ & $\begin{array}{l}\text { University Hospital, } \\
\text { Würzburg, Germany }\end{array}$ & $\begin{array}{l}\text { Co- } \\
\text { investigator }\end{array}$ & $\begin{array}{l}\text { Organizational } \\
\text { Support }\end{array}$ \\
\hline $\begin{array}{l}\text { Annette } \\
\text { Spreer, MD }\end{array}$ & $\begin{array}{l}\text { University Medical } \\
\text { Center of the } \\
\text { Johannes Gutenberg } \\
\text { University, Mainz, } \\
\text { Germany }\end{array}$ & $\begin{array}{l}\text { Co- } \\
\text { investigator }\end{array}$ & $\begin{array}{l}\text { Organizational } \\
\text { Support }\end{array}$ \\
\hline $\begin{array}{l}\text { Martin } \\
\text { Stangel, MD }\end{array}$ & $\begin{array}{l}\text { Hannover Medical } \\
\text { School, Hannover, } \\
\text { Germany }\end{array}$ & $\begin{array}{l}\text { Co- } \\
\text { investigator }\end{array}$ & $\begin{array}{l}\text { Organizational } \\
\text { Support }\end{array}$ \\
\hline $\begin{array}{l}\text { Andrea } \\
\text { Steinbrecher, } \\
\text { MD }\end{array}$ & $\begin{array}{l}\text { Helios Klinikum, } \\
\text { Erfurt, Germany }\end{array}$ & $\begin{array}{l}\text { Co- } \\
\text { investigator }\end{array}$ & $\begin{array}{l}\text { Organizational } \\
\text { Support }\end{array}$ \\
\hline $\begin{array}{l}\text { Heike } \\
\text { Stephanik, } \\
\text { MD }\end{array}$ & $\begin{array}{l}\text { University Hospital, } \\
\text { Magdeburg, } \\
\text { Germany }\end{array}$ & $\begin{array}{l}\text { Co- } \\
\text { investigator }\end{array}$ & $\begin{array}{l}\text { Organizational } \\
\text { Support }\end{array}$ \\
\hline $\begin{array}{l}\text { Muriel } \\
\text { Stoppe, MD }\end{array}$ & $\begin{array}{l}\text { University Hospital, } \\
\text { Leipzig, Germany }\end{array}$ & $\begin{array}{l}\text { Co- } \\
\text { investigator }\end{array}$ & $\begin{array}{l}\text { Organizational } \\
\text { Support }\end{array}$ \\
\hline $\begin{array}{l}\text { Marie Süße, } \\
\text { MD }\end{array}$ & $\begin{array}{l}\text { University Hospital, } \\
\text { Greifswald, Germany }\end{array}$ & $\begin{array}{l}\text { Co- } \\
\text { investigator }\end{array}$ & $\begin{array}{l}\text { Organizational } \\
\text { Support }\end{array}$ \\
\hline $\begin{array}{l}\text { Björn } \\
\text { Tackenberg, } \\
\text { MD }\end{array}$ & $\begin{array}{l}\text { University Hospital, } \\
\text { Marburg, Germany }\end{array}$ & $\begin{array}{l}\text { Co- } \\
\text { investigator }\end{array}$ & $\begin{array}{l}\text { Organizational } \\
\text { Support }\end{array}$ \\
\hline $\begin{array}{l}\text { Florian Then- } \\
\text { Bergh, MD }\end{array}$ & $\begin{array}{l}\text { University Hospital, } \\
\text { Leipzig, Germany }\end{array}$ & $\begin{array}{l}\text { Co- } \\
\text { investigator }\end{array}$ & $\begin{array}{l}\text { Organizational } \\
\text { Support }\end{array}$ \\
\hline $\begin{array}{l}\text { Johannes } \\
\text { Tünnerhoff, } \\
\text { MD }\end{array}$ & $\begin{array}{l}\text { University Hospital, } \\
\text { Tübingen, Germany }\end{array}$ & $\begin{array}{l}\text { Co- } \\
\text { investigator }\end{array}$ & $\begin{array}{l}\text { Organizational } \\
\text { Support }\end{array}$ \\
\hline $\begin{array}{l}\text { Hayrrettin } \\
\text { Tumani, MD }\end{array}$ & $\begin{array}{l}\text { University Hospital, } \\
\text { Ulm, Germany }\end{array}$ & $\begin{array}{l}\text { Co- } \\
\text { investigator }\end{array}$ & $\begin{array}{l}\text { Organizational } \\
\text { Support }\end{array}$ \\
\hline $\begin{array}{l}\text { Annette } \\
\text { Walter, MD }\end{array}$ & $\begin{array}{l}\text { Klinikum Herford, } \\
\text { Herford, Germany }\end{array}$ & $\begin{array}{l}\text { Co- } \\
\text { investigator }\end{array}$ & $\begin{array}{l}\text { Organizational } \\
\text { Support }\end{array}$ \\
\hline
\end{tabular}

Appendix 2 (continued)

Members of the Neuromyelitis Optica Study Group (NEMOS) are listed below in alphabetical order.

\begin{tabular}{|c|c|c|c|}
\hline Name & Location & Role & Contribution \\
\hline $\begin{array}{l}\text { Klaus-Peter } \\
\text { Wandinger, } \\
\text { MD }\end{array}$ & $\begin{array}{l}\text { University Medical } \\
\text { Center Schleswig- } \\
\text { Holstein Campus, } \\
\text { Lübeck, Germany }\end{array}$ & $\begin{array}{l}\text { Co- } \\
\text { investigator }\end{array}$ & $\begin{array}{l}\text { Organizational } \\
\text { Support }\end{array}$ \\
\hline $\begin{array}{l}\text { Clemens } \\
\text { Warnke, MD }\end{array}$ & $\begin{array}{l}\text { University Hospital, } \\
\text { Köln, Germany }\end{array}$ & $\begin{array}{l}\text { Co- } \\
\text { investigator }\end{array}$ & $\begin{array}{l}\text { Organizational } \\
\text { Support }\end{array}$ \\
\hline $\begin{array}{l}\text { Robert } \\
\text { Weissert, MD }\end{array}$ & $\begin{array}{l}\text { University Hospital, } \\
\text { Regensburg, } \\
\text { Germany }\end{array}$ & $\begin{array}{l}\text { Co- } \\
\text { investigator }\end{array}$ & $\begin{array}{l}\text { Organizational } \\
\text { Support }\end{array}$ \\
\hline $\begin{array}{l}\text { Heinz Wiendl, } \\
\text { MD }\end{array}$ & $\begin{array}{l}\text { University Hospital, } \\
\text { Münster, Germany }\end{array}$ & $\begin{array}{l}\text { Co- } \\
\text { investigator }\end{array}$ & $\begin{array}{l}\text { Organizational } \\
\text { Support }\end{array}$ \\
\hline $\begin{array}{l}\text { Christian } \\
\text { Wilke, MD }\end{array}$ & $\begin{array}{l}\text { Nervenzentrum, } \\
\text { Potsdam, Germany }\end{array}$ & $\begin{array}{l}\text { Co- } \\
\text { investigator }\end{array}$ & $\begin{array}{l}\text { Organizational } \\
\text { Support }\end{array}$ \\
\hline $\begin{array}{l}\text { Alexander } \\
\text { Winkelmann, } \\
\text { MD }\end{array}$ & $\begin{array}{l}\text { University Hospital, } \\
\text { Rostock, Germany }\end{array}$ & $\begin{array}{l}\text { Co- } \\
\text { investigator }\end{array}$ & $\begin{array}{l}\text { Organizational } \\
\text { Support }\end{array}$ \\
\hline $\begin{array}{l}\text { Yavor } \\
\text { Yalachkov, } \\
\text { MD }\end{array}$ & $\begin{array}{l}\text { University Hospital, } \\
\text { Frankfurt, Germany }\end{array}$ & $\begin{array}{l}\text { Co- } \\
\text { investigator }\end{array}$ & $\begin{array}{l}\text { Organizational } \\
\text { Support }\end{array}$ \\
\hline $\begin{array}{l}\text { Lena Zeltner, } \\
\text { MD }\end{array}$ & $\begin{array}{l}\text { University Hospital, } \\
\text { Tübingen, Germany }\end{array}$ & $\begin{array}{l}\text { Co- } \\
\text { investigator }\end{array}$ & $\begin{array}{l}\text { Organizational } \\
\text { Support }\end{array}$ \\
\hline Uwe Zettl & $\begin{array}{l}\text { University Hospital, } \\
\text { Rostock, Germany }\end{array}$ & $\begin{array}{l}\text { Co- } \\
\text { investigator }\end{array}$ & $\begin{array}{l}\text { Organizational } \\
\text { Support }\end{array}$ \\
\hline $\begin{array}{l}\text { Ulf Ziemann, } \\
\text { MD }\end{array}$ & $\begin{array}{l}\text { University Hospital, } \\
\text { Tübingen, Germany }\end{array}$ & $\begin{array}{l}\text { Co- } \\
\text { investigator }\end{array}$ & $\begin{array}{l}\text { Organizational } \\
\text { Support }\end{array}$ \\
\hline $\begin{array}{l}\text { Frauke Zipp, } \\
\text { MD }\end{array}$ & $\begin{array}{l}\text { University Medical } \\
\text { Center of the } \\
\text { Johannes Gutenberg } \\
\text { University, Mainz, } \\
\text { Germany }\end{array}$ & $\begin{array}{l}\text { Co- } \\
\text { investigator }\end{array}$ & $\begin{array}{l}\text { Organizational } \\
\text { Support }\end{array}$ \\
\hline
\end{tabular}

\section{References}

1. Weinshenker BG, Wingerchuk DM. Neuromyelitis spectrum disorders. Mayo Clin Proc 2017;92(4):663-679.

2. Fujihara K. Neuromyelitis optica spectrum disorders: still evolving and broadening. Curr Opin Neurol 2019;32(3):385-394.

3. Paul F, Jarius $\mathrm{S}$, Aktas $\mathrm{O}$, et al. Antibody to aquaporin 4 in the diagnosis of neuromyelitis optica. PLoS Med 2007;4(4):e133.

4. Hillebrand S, Schanda K, Nigritinou M, et al. Circulating AQP4-specific autoantibodies alone can induce neuromyelitis optica spectrum disorder in the rat. Act Neuropathol 2019;137(3):467-485.

5. Jarius S, Ruprecht K, Wildemann B, et al. Contrasting disease patterns in seropositive and seronegative neuromyelitis optica: a multicentre study of 175 patients. J Neuroinflammation 2012;9:14

6. Kleiter I, Gahlen A, Borisow N, et al. Neuromyelitis optica: evaluation of 871 attacks and 1153 treatment courses. Ann Neurol 2016;79(2):206-216.

7. Moore P, Methley A, Pollard C, et al. Cognitive and psychiatric comorbidities in neuromyelitis optica. J Neurol Sci 2016;360:4-9.

8. Beekman J, Keisler A, Pedraza O, et al. Neuromyelitis optica spectrum disorder: patient experience and quality of life. Neurol Neuroimmunol Neuroinflamm 2019; 6(4):e580.

9. Jarius S, Wildemann B. The history of neuromyelitis optica. Part 2: 'Spinal amaurosis', or how it all began. J Neuroinflammation 2019;16(1):280.

10. Kanamori $Y$, Nakashima I, Takai $Y$, et al. Pain in neuromyelitis optica and its effect on quality of life: a cross-sectional study. Neurology 2011;77(7):652-658.

11. Qian P, Lancia S, Alvarez E, et al. Association of neuromyelitis optica with severe and intractable pain. Arch Neurol 2012;69(11):1482-1487.

12. Zhao S, Mutch K, Elsone L, et al. Neuropathic pain in neuromyelitis optica affects activities of daily living and quality of life. Mult Scler 2014;20(12):1658-1661.

13. Kong $\mathrm{Y}$, Okoruwa $\mathrm{H}$, Revis J, et al. Pain in patients with transverse myelitis and its relationship to aquaporin 4 antibody status. J Neurol Sci 2016;368:84-88. 
14. Asseyer S, Schmidt F, Chien C, et al. Pain in AQP4-IgG-positive and MOG-IgGpositive neuromyelitis optica spectrum disorders. Mult Scler J Exp Transl Clin 2018; 4(3):2055217318796684.

15. Hyun JW, Jang H, Yu J, et al. Comparison of neuropathic pain in neuromyelitis optica spectrum disorder and multiple sclerosis. J Clin Neurol 2020;16(1):124-130.

16. Bradl M, Kanamori Y, Nakashima I, et al. Pain in neuromyelitis optica-prevalence, pathogenesis and therapy. Nat Rev Neurol 2014;10(9):529-536.

17. Kim SM, Go MJ, Sung JJ, et al. Painful tonic spasm in neuromyelitis optica: incidence, diagnostic utility, and clinical characteristics. Arch Neurol 2012;69(8): 1026-1031.

18. Yamamura T, Kleiter I, Fujihara K, et al. Trial of satralizumab in neuromyelitis optica spectrum disorder. N Engl J Med 2019;381(22):2114-2124.

19. Wingerchuk DM, Banwell B, Bennett JL, et al. International consensus diagnostic criteria for neuromyelitis optica spectrum disorders. Neurology 2015;85(2):177-189.

20. Freynhagen R, Baron R, Gockel U, et al. painDETECT: a new screening questionnaire to identify neuropathic components in patients with back pain. Curr Med Res Opin 2006;22(10):1911-1920.

21. Melzack R. The short-form McGill pain questionnaire. Pain 1987;30(2):191-197.

22. Fox J, Weisberg A. An R Companion to Applied Regression. 3rd ed. SAGE Publications Inc.; 2018.
23. Tackley G, Vecchio D, Hamid S, et al. Chronic neuropathic pain severity is determined by lesion level in aquaporin 4-antibody-positive myelitis. J Neurol Neurosurg Psychiatry 2017;88(2):165-169.

24. Muller R, Brinkhof MW, Arnet U, et al. Prevalence and associated factors of pain in the Swiss spinal cord injury population. Spinal Cord 2017;55(4):346-354.

25. Tuzun E, Akman-Demir G, Eraksoy M. Paroxysmal attacks in multiple sclerosis. Mult Scler 2001;7(6):402-404.

26. Spissu A, Cannas A, Ferrigno P, et al. Anatomic correlates of painful tonic spasms in multiple sclerosis. Mov Disord 1999;14(2):331-335.

27. Chavarro VS, Mealy MA, Simpson A, et al. Insufficient treatment of severe depression in neuromyelitis optica spectrum disorder. Neurol Neuroimmunol Neuroinflamm 2016;3(6):e286

28. Walker AK, Kavelaars A, Heijnen CJ, et al. Neuroinflammation and comorbidity of pain and depression. Pharmacol Rev 2014;66(1):80-101.

29. Skucas VA, Mathews IB, Yang J, et al. Impairment of select forms of spatial memory and neurotrophin-dependent synaptic plasticity by deletion of glial aquaporin-4. J Neurosci 2011;31(17):6392-6397.

30. Mealy MA, Kozachik SL, Cook LJ, et al. Scrambler therapy improves pain in neuromyelitis optica: a randomized controlled trial. Neurology 2020;94(18) e1900-e07. 


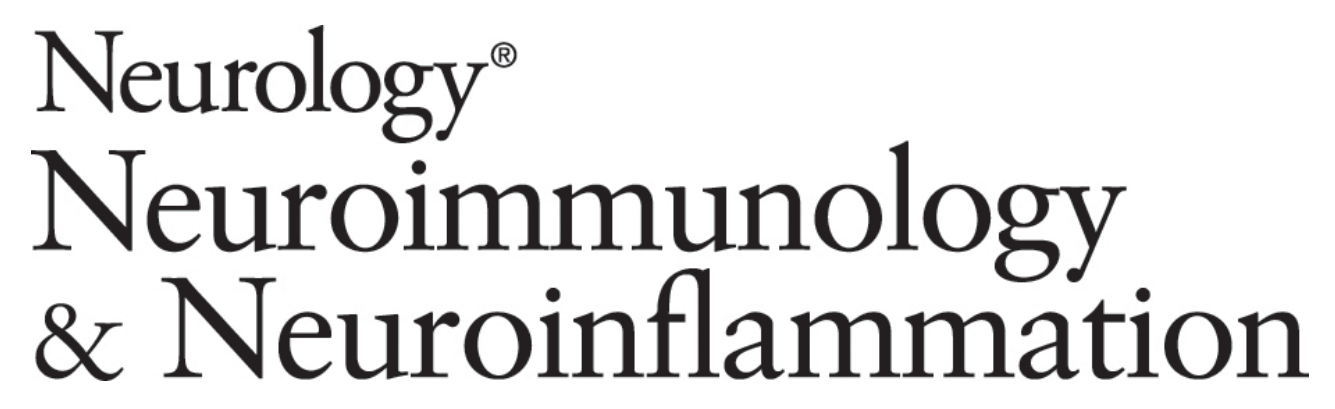

Pain, Depression, and Quality of Life in Neuromyelitis Optica Spectrum Disorder: A Cross-Sectional Study of 166 AQP4 Antibody-Seropositive Patients

Ilya Ayzenberg, Daniel Richter, Eugenia Henke, et al.

Neurol Neuroimmunol Neuroinflamm 2021;8;

DOI 10.1212/NXI.0000000000000985

This information is current as of April 20, 2021

Neurol Neuroimmunol Neuroinflamm is an official journal of the American Academy of Neurology.

Published since April 2014, it is an open-access, online-only, continuous publication journal. Copyright

Copyright $\odot 2021$ The Author(s). Published by Wolters Kluwer Health, Inc. on behalf of the American

Academy of Neurology.. All rights reserved. Online ISSN: 2332-7812.

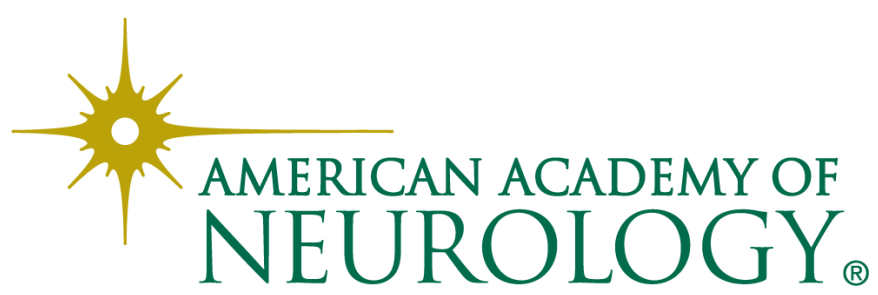




\section{Updated Information \& Services}

References

Citations

Subspecialty Collections

Permissions \& Licensing

Reprints including high resolution figures, can be found at: http://nn.neurology.org/content/8/3/e985.full.html

This article cites 29 articles, 4 of which you can access for free at: http://nn.neurology.org/content/8/3/e985.full.html\#\#ref-list-1

This article has been cited by 1 HighWire-hosted articles: http://nn.neurology.org/content/8/3/e985.full.html\#\#otherarticles

This article, along with others on similar topics, appears in the following collection(s):

All Clinical Neurology

http://nn.neurology.org//cgi/collection/all_clinical_neurology All Pain

http://nn.neurology.org//cgi/collection/all_pain

Central pain

http://nn.neurology.org//cgi/collection/central_pain

Devic's syndrome

http://nn.neurology.org//cgi/collection/devics_syndrome

Neuropathic pain

http://nn.neurology.org//cgi/collection/neuropathic_pain

Information about reproducing this article in parts (figures,tables) or in its entirety can be found online at:

http://nn.neurology.org/misc/about.xhtml\#permissions

Information about ordering reprints can be found online:

http://nn.neurology.org/misc/addir.xhtml\#reprintsus

Neurol Neuroimmunol Neuroinflamm is an official journal of the American Academy of Neurology.

Published since April 2014, it is an open-access, online-only, continuous publication journal. Copyright

Copyright $\odot 2021$ The Author(s). Published by Wolters Kluwer Health, Inc. on behalf of the American

Academy of Neurology.. All rights reserved. Online ISSN: 2332-7812.

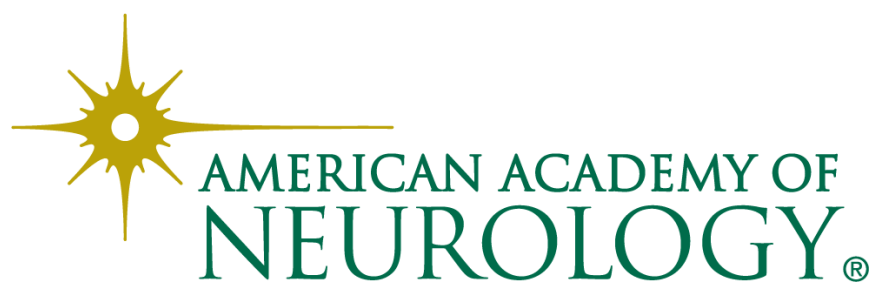

